\title{
Trace gas and particle emissions from domestic and industrial biofuel use and garbage burning in central Mexico
}

\author{
T. J. Christian ${ }^{1}$, R. J. Yokelson ${ }^{1}$, B. Cárdenas ${ }^{2}$, L. T. Molina ${ }^{3,4}$, G. Engling ${ }^{5}$, and S.-C. Hsu ${ }^{5}$ \\ ${ }^{1}$ University of Montana, Department of Chemistry, Missoula, MT, USA \\ ${ }^{2}$ National Center for Environmental Research and Training, National Institute of Ecology/SEMARNAT, Mexico, DF, Mexico \\ ${ }^{3}$ Department of Earth, Atmospheric and Planetary Science, Massachusetts Institute of Technology, Cambridge, MA, USA \\ ${ }^{4}$ Molina Center for Energy and Environment, La Jolla, CA, USA \\ ${ }^{5}$ Research Center for Environmental Changes, Academia Sinica, Taipei, Taiwan, ROC, Taiwan
}

Received: 1 April 2009 - Published in Atmos. Chem. Phys. Discuss.: 21 April 2009

Revised: 23 December 2009 - Accepted: 23 December 2009 - Published: 21 January 2010

\begin{abstract}
In central Mexico during the spring of 2007 we measured the initial emissions of 12 gases and the aerosol speciation for elemental and organic carbon (EC, OC), anhydrosugars, $\mathrm{Cl}^{-}, \mathrm{NO}_{3}^{-}$, and 20 metals from 10 cooking fires, four garbage fires, three brick making kilns, three charcoal making kilns, and two crop residue fires. Global biofuel use has been estimated at over $2600 \mathrm{Tg} / \mathrm{y}$. With several simple case studies we show that cooking fires can be a major, or the major, source of several gases and fine particles in developing countries. Insulated cook stoves with chimneys were earlier shown to reduce indoor air pollution and the fuel use per cooking task. We confirm that they also reduce the emissions of VOC pollutants per mass of fuel burned by about half. We did not detect $\mathrm{HCN}$ emissions from cooking fires in Mexico or Africa. Thus, if regional source attribution is based on $\mathrm{HCN}$ emissions typical for other types of biomass burning (BB), then biofuel use and total BB will be underestimated in much of the developing world. This is also significant because cooking fires are not detected from space. We estimate that $\sim 2000 \mathrm{Tg} / \mathrm{y}$ of garbage are generated globally and about half may be burned, making this a commonly overlooked major global source of emissions. We estimate a fine particle emission factor $\left(\mathrm{EFPM}_{2.5}\right)$ for garbage burning of $\sim 10.5 \pm 8.8 \mathrm{~g} / \mathrm{kg}$, which is in reasonable agreement with very limited previous work. We observe large $\mathrm{HCl}$ emission factors in the range $2-10 \mathrm{~g} / \mathrm{kg}$. Consideration of the $\mathrm{Cl}$ content of the global waste stream suggests that garbage burning
\end{abstract}

Correspondence to: R. J. Yokelson

(bob.yokelson@umontana.edu) may generate as much as $6-9 \mathrm{Tg} / \mathrm{yr}$ of $\mathrm{HCl}$, which would make it a major source of this compound. $\mathrm{HCl}$ generated by garbage burning in dry environments may have a relatively greater atmospheric impact than $\mathrm{HCl}$ generated in humid areas. Garbage burning $\mathrm{PM}_{2.5}$ was found to contain levoglucosan and $\mathrm{K}$ in concentrations similar to those for biomass burning, so it could be a source of interference in some areas when using these tracers to estimate BB. Galactosan was the anhydrosugar most closely correlated with $\mathrm{BB}$ in this study. Fine particle antimony ( $\mathrm{Sb}$ ) shows initial promise as a garbage burning tracer and suggests that this source could contribute a significant amount of the $\mathrm{PM}_{2.5}$ in the Mexico City metropolitan area. The fuel consumption and emissions due to industrial biofuel use are difficult to characterize regionally. This is partly because of the diverse range of fuels used and the very small profit margins of typical microenterprises. Brick making kilns produced low total $\mathrm{EFPM}_{2.5}$ $(\sim 1.6 \mathrm{~g} / \mathrm{kg})$, but very high EC/OC ratios (6.72). Previous literature on brick kilns is scarce but does document some severe local impacts. Coupling data from Mexico, Brazil, and Zambia, we find that charcoal making kilns can exhibit an 8-fold increase in VOC/CO over their approximately oneweek lifetime. Acetic acid emission factors for charcoal kilns were much higher in Mexico than elsewhere. Our dirt charcoal kiln $\mathrm{EFPM}_{2.5}$ emission factor was $\sim 1.1 \mathrm{~g} / \mathrm{kg}$, which is lower than previous recommendations intended for all types of kilns. We speculate that some $\mathrm{PM}_{2.5}$ is scavenged in the walls of dirt kilns.

Published by Copernicus Publications on behalf of the European Geosciences Union. 


\section{Introduction}

In developed countries most of the urban combustion emissions are due to burning fossil fuels. Fossil fuel emissions are also a major fraction of the air pollution in the urban areas of developing countries. However, in the developing world, the urban areas are embedded within a region that features numerous, small-scale, loosely regulated combustion sources due to domestic and industrial use of biomass fuel (biofuel) and the burning of garbage and crop residues. The detailed chemistry of the emissions from these sources has not been available and the degree to which these emissions affect air chemistry in urban regions of the developing world has been difficult to assess. As an example, we note that Raga et al. (2001) reviewed 40 years of air quality measurements in Mexico City (MC) and concluded that more work was needed on source characterization of non fossil-fuel combustion sources before more effective air pollution mitigation strategies could be implemented. The 2003 MCMA (Mexico City Metropolitan Area) campaign (Molina et al., 2007) and the 2006 MILAGRO (Megacity Initiative: Local and Global Research Observations) campaign. Molina et al. (2008) focused on fixed-point monitoring of the complex MCMA mix of pollutants at heavily instrumented ground stations and on airborne studies of the outflow from the MCMA region. Explicit source characterization for biomass fires in the MCMA region was part of MILAGRO 2006, but only for landscapescale open burning (e.g. forest fires in the mountains adjacent to MCMA, Yokelson et al., 2007).

Our 2007 ground-based MILAGRO campaign employed an approach that was complementary to most of the earlier work. With a highly mobile suite of instruments, we actively located representative sources of biofuel and garbage burning on the periphery of the MCMA and throughout central Mexico and measured the initial trace gas and particle emissions directly within the visible effluent plumes of these sources. The results should help interpret the data from both the fixed monitoring stations in the MCMA (e.g. $T_{0}, T_{1}, T_{2}$, etc.) and from aircraft in the outflow, (Molina et al., 2008). Our source characterization also has global significance due to the widespread occurrence of these sources throughout the developing world as summarized next.

Recent global estimates of annual biofuel consumption include $2897 \mathrm{Tg}$ dry matter (dm)/y (Andreae and Merlet, 2001) and $2457 \mathrm{Tg} \mathrm{dm} / \mathrm{y}$ (Fernandes et al., 2007), making it the second largest type of global biomass burning after savanna fires. An estimated $80 \%$ of the biofuel is consumed for domestic cooking, heating, and lighting mostly in open cooking fires burning wood, agricultural waste, charcoal, or dung within homes (Dherani et al., 2008). The balance of the biofuel is consumed mostly by low-technology, largely unregulated, micro-enterprises such as brick or tile making kilns, restaurants, tanneries, etc. While individual "informal firms" are small, their total number is very large, e.g. $\sim 20000$ brick making kilns in Mexico (Blackman and Bannister, 1998).
Thus, this "informal sector" of the economy accounts for over $50 \%$ of non-agricultural employment and $25-75 \%$ of gross domestic product in both Latin America and Africa (Ranis and Stewart, 1994; Schneider and Enste, 2000). Biofuel use is thought to occur mainly in peri-urban and rural areas where biofuel is readily available although use of transported charcoal is known to occur in cities (Bertschi et al., 2003). The quantification of biofuel use has been based on surveys of the rural population and there are not good estimates of how much may occur in urban areas.

McCulloch et al. (1999) calculated the 1990 garbage production from the 4.5 billion people included in the Reactive Chlorine Emissions Inventory as $1500 \mathrm{Tg}$. Scaling to the current global population of 6 billion suggests that $2000 \mathrm{Tg}$ is an approximate, present global value. If half of this garbage is burned in open fires or incinerators (McCulloch et al., 1999) and it is $50 \% \mathrm{C}$, it would add $500 \mathrm{Tg}$ of $\mathrm{C}$ to the atmosphere annually. This is about $7 \%$ of the $\mathrm{C}$ added by all fossil fuel burning (Forster et al., 2007). This crude estimate is fairly consistent with data from the remote Pacific in which $11 \pm 7 \%$ of the total identified organic mass in the ambient aerosol was phthalates, ostensibly from garbage burning (Table 6, Simoneit et al., 2004b). It is most economical to burn urbangenerated garbage in, or near, the major population centers that produce it. In addition, an estimated $12-40 \%$ of households in rural areas of the US burn trash in their backyards, (USEPA, 2006). Thus, most garbage burning occurs in close proximity to people, despite estimates that garbage burning is the major global source of some especially hazardous air toxics such as dioxins (Costner, 2005, 2006).

The burning of crop residue in fields is generally considered to be the fourth largest type of global biomass burning with estimates including $540 \mathrm{Tg} \mathrm{dm} / \mathrm{y}$ (Andreae and Merlet, 2001) and $475 \mathrm{Tg} \mathrm{dm} / \mathrm{y}$ (Bond et al., 2004). Because cities are often located in prime agricultural regions, they may expand into areas where crop residue burning is a major activity and is sometimes the dominant local source of air pollution, (Cançado et al., 2006).

In this study we measured the initial emissions of 12 of the most abundant gases, and the aerosol speciation for elemental and organic carbon (EC, OC), anhydrosugars, $\mathrm{Cl}^{-}$, $\mathrm{NO}_{3}^{-}$, and 20 metals from domestic and industrial biofuel use, garbage burning, and crop residue fires. In the following sections the measurements are described in detail and the implications of selected results are discussed.

\section{Experimental details}

\subsection{Source types and site descriptions}

We ranged by truck and van from Mexico City $\sim 100 \mathrm{~km}$ to the north, east, and southeast, and $\sim 300 \mathrm{~km}$ to the west over the course of about one month in April-May 2007. The emissions data presented here were obtained from the general 
Table 1. Sampling source types and locations.

\begin{tabular}{|c|c|c|c|c|}
\hline Type & Location & Date (2007) & Lat & Lon \\
\hline Open cook & San Pedro Benito Juárez, Atlixco, Puebla & $18 \mathrm{Apr}$ & 18.95 & -98.55 \\
\hline Open cook & San Pedro Benito Juárez, Atlixco, Puebla & 19 Apr & 18.95 & -98.55 \\
\hline Open cook & San Juan Tumbio, Michoacán & 8 May & 19.50 & -101.77 \\
\hline Open cook & San Juan Tumbio, Michoacán & 8 May & 19.50 & -101.77 \\
\hline Open cook & Comachuén, Michoacán & 9 May & 19.57 & -101.90 \\
\hline Open cook & Comachuén, Michoacán & 9 May & 19.57 & -101.90 \\
\hline Open cook & Comachuén, Michoacán & 9 May & 19.57 & -101.90 \\
\hline Open cook & GIRA lab, Tzentzenguaro, Michoacán & 10 May & 19.53 & -101.64 \\
\hline Patsari cook & GIRA lab, Tzentzenguaro, Michoacán & 10 May & 19.53 & -101.64 \\
\hline Patsari cook & Rancho de Álvarez, Michoacán & 11 May & 19.54 & -101.51 \\
\hline Charcoal kiln & San Gaspar de lo Bendito, Atlixco, Puebla & 17 Apr & 19.00 & -98.54 \\
\hline Charcoal kiln ${ }^{\mathrm{a}}$ & Hueyitlapichco, Atlixco, Puebla & 19 Apr & 18.97 & -98.56 \\
\hline Charcoal kiln ${ }^{\mathrm{a}}$ & Hueyitlapichco, Atlixco, Puebla & $20 \mathrm{Apr}$ & 18.97 & -98.56 \\
\hline Brick making kiln & Teoloyucan, Edo. México & $24 \mathrm{Apr}$ & 19.77 & -99.19 \\
\hline Brick making kiln & Barrio México 86, Edo. México & 27 Apr & 19.41 & -98.91 \\
\hline Brick making kiln & Silao, Guanajuato & 2 May & 20.94 & -101.42 \\
\hline Landfill & Soyaniquilpan, Edo. México & $23 \mathrm{Apr}$ & 20.01 & -99.49 \\
\hline Landfill & Coyotepec, Edo. México & $24 \mathrm{Apr}$ & 19.81 & -99.22 \\
\hline Landfill & Tolcayuca, Hidalgo & $25 \mathrm{Apr}$ & 19.97 & -98.92 \\
\hline Landfill & San Martín de las Pirámides, Edo. Mex. & $26 \mathrm{Apr}$ & 19.70 & -98.80 \\
\hline Barley stubble & Rancho de Don Ignacio, Guanajuato & $30 \mathrm{Apr}$ & 20.60 & -101.22 \\
\hline Barley stubble & Rancho de Don Ignacio, Guanajuato & 1 May & 20.60 & -101.22 \\
\hline
\end{tabular}

a Two separate kilns at one location.

source types listed in Table 1 and shown in a map available as supplementary material (http://www.atmos-chem-phys. net/10/565/2010/acp-10-565-2010-supplement.pdf). The sources include eight indoor open wood cooking fires, two indoor wood cooking fires in Patsari stoves, three charcoal making kilns (from two sites), three brick making kilns, four garbage burns in peri-urban landfills, and two barley stubble field burns.

All but one of the open wood cooking fire measurements were conducted in rural and semi-rural homes during actual cooking episodes. The cooking fire in the laboratory of the Interdisciplinary Group on Appropriate Rural Technology (GIRA) was a simulation using an authentic open cook stove and typical fuel wood. For six of the eight homes in which we sampled, the kitchen was housed in a separate building. For the other two, the kitchen was part of the main dwelling with a wall separating it from the sleeping area. Ventilation in all cases was by passive draft through door and window openings, cracks in the walls between boards, and horizontal openings where roof meets wall. Six of the eight kitchens had a dirt floor, seven were constructed of wood and one of brick. A variety of biofuels were available to the homeowners, including wood, corn cobs, corn stalks, and charcoal. The primary fuel in all these homes, and the fuel used in all the fires we measured, was oak or pine collected locally by hand. Cooking fires were built either directly on the ground within a ring of three rocks, or on a mud and mortar, u-shaped, raised open stove. In one instance the "stove" was a dirt-filled metal bucket with rocks on top. In the homes that we visited a typical food preparation regimen began with a small, hot, flaming fire to quickly boil a pot of water, which is then loaded with beans and set off to the side to simmer. As the fire begins to die back, the cook begins making tortillas. Wood is fed gradually to the fire to maintain the right amount of heat and when the cooking ends the fire is generally snuffed out to conserve fuel. A cooking session might last several hours depending on how much food is needed in the next few days. The sample lines of all the instruments were co-located at $\sim 1 \mathrm{~m}$ above the fire over the course of the cooking operation. The cook and her youngest children typically remain inside the kitchen for as long as it takes to prepare the food.

The Patsari stove incorporates an insulated fire box that is vented to the outdoors by a metal chimney. It is the product of 15 years of work by GIRA and the Center for Ecosystems Research (CIECO) to improve stoves economically (Masera et al., 2005). The stove cuts fuel consumption "per cooking task" roughly in half so its widespread adoption could reduce the total emissions from biofuel use. The chimney provides an approximate $70 \%$ reduction in indoor air pollution (Zuk et al., 2007). Indoor air pollution is believed to be one of the major risk factors for pneumonia, which is the 
largest single cause of mortality globally in children under five (Smith et al., 2004; Dherani et al., 2008). It is also of interest that reactions on the chimney surface could modify the emissions (Christian et al., 2007). The chimney does not eliminate all the indoor pollutants because the fire box has an open front that can leak emissions into the room. Also, the chimney emissions may at times be recirculated into the kitchen from outdoors. We sequentially measured first the kitchen air above the stove, and then the chimney emissions from two different Patsari stoves in Pátzcuaro. One was located in a rural kitchen and the other was a newer model located in the GIRA lab's simulated kitchen.

We sampled three charcoal making kilns in a forested area between MC and Puebla. An excavation $\sim 5 \mathrm{~m}$ in diameter is dug by hand and kindling (dry needles, leaves, and twigs) is laid down. Oak logs are stacked in the center and a network of interlaced green oak branches is placed over the top. The excavated dirt is then packed on top to complete the earthen kiln, which has about a dozen vents around the circumference. A kiln of this design yields $200-250 \mathrm{~kg}$ of charcoal in about eight days. The supporting oak branches burn away slowly and the kiln must be rebuilt once or more during its lifetime to prevent it from collapsing and smothering the fire. The two kilns at the Hueyitlapichco site were constructed on consecutive days. We sampled them on their second and third day of operation on 19 April, and on their third and fourth day of operation on 20 April. At the San Gaspar site we sampled a single kiln on its fifth day of operation.

Brick making kilns in central Mexico are constructed from bricks. The fire bed and base walls are permanent and often built at the bottom of an excavation, which provides some insulation for the fire bed. There are several large, permanent mortar or concrete "crossbeams" above the fire bed. Green bricks are stacked to a height of several meters on the crossbeams (spaced to allow even heat circulation). Brick walls and a roof are then built up around the whole assembly. A fire is lit and fuel is shoveled or thrown in until the desired temperature is reached. Fuel is then added, as needed, to maintain that temperature around the clock for 1-2 days. At varying times each kiln operator uses mortar to seal the walls and most of the roof. Some owners allow the kiln to ventilate freely through the walls and roof for a day before sealing with mortar, claiming this gives a more uniform bake. Others seal the walls and roof before ignition. Kilns number 1 and 2 were burning fuel that was mostly wood waste products that had been hauled onto the site by dump truck. About $90 \%$ of this fuel was sawdust by volume. The remainder was divided fairly evenly between wood scraps, plywood, and particle board. A small fraction (less than 1\%) was paper and cardboard. Brick kiln number 3 was using only scrap lumber while we made measurements. We were unable to visit a fourth kiln near Silao that was reportedly burning used motor oil for fuel and a fifth kiln near Salamanca that was burning domestic waste scavenged from a nearby landfill. The raw material for bricks is soil carved by hand from the ground in the vicinity of the kiln. The soil is mixed with water and manure or other organic waste and stomped barefoot to form a thick paste. The paste is then pressed into a mold and overturned one by one into rows to dry in the sun. Once they are dry enough to handle, the green bricks are stacked (in the shade if possible) and covered to prevent too rapid drying and cracking. Two of the brick kilns were sized to fire 1012000 bricks at a time; the third (brick kiln 2) was about three times larger. Kilns of this design are typical for Latin America and Africa, while more efficient designs - and coal fuel - are more common in Asia.

All four garbage burning fires were in the municipal landfills of peri-urban communities north of Mexico City. Only one landfill (Coyotepec, garbage fire 2) was burning when we arrived. At the other three sites we ignited relatively small, representative sections of refuse under the direction of local authorities. The landfills held typical household and light industrial refuse. Plastic was by far the most abundant material present. The following list is an approximate accounting of the composition of the waste stream for these landfills, in roughly diminishing order:

- plastic: bottles, bags, buckets, containers, toys, wrappers, Styrofoam

- paper: newspaper, magazines, cardboard boxes, food containers

- organic: fruit, vegetables (food waste)

- textile/synthetic fiber: cotton/nylon clothing, scraps

- rubber/leather: neoprene (in one case), sandals, shoes, scraps

- glass: bottles, jars

- vegetation: garden waste, brush, grass

- metal: soup cans, buckets, oil filters, aluminum foil

- ceramic: cups, dishes, cookware

- other waste materials

It appeared that tires were piled separately and perhaps not burned intentionally at the landfills. Wood was absent from any of the landfills since it is the most common cooking fuel in Mexico. The Tolcayuca landfill (garbage fire 3) was located in a textile manufacturing area and contained a higher proportion of textile waste than the other landfills. Each landfill was attended by people who manually removed items of value, including recyclable plastic bottles and cardboard. The scavenging process was less than perfectly efficient and small portions of the "collectible" waste did get included in the burns. All of our measurements were made from fires burning in the processed refuse from which the bulk of the recyclables had already been removed. 


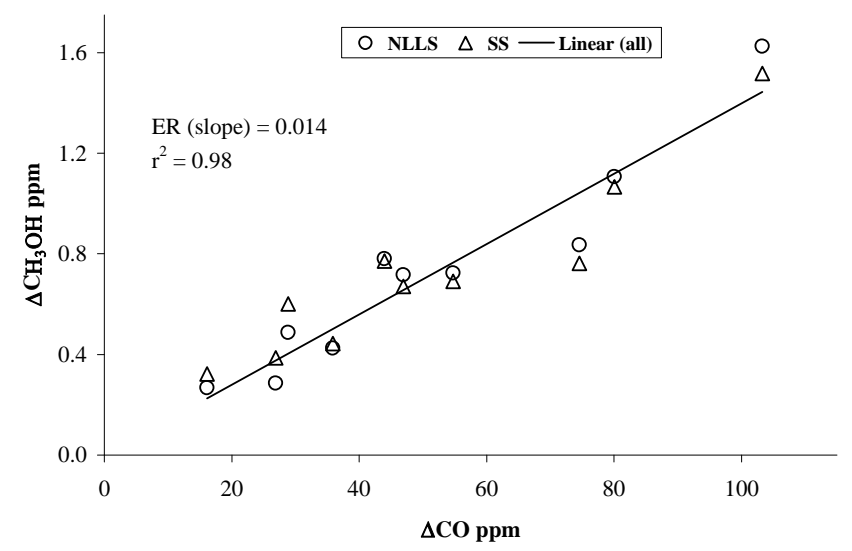

Fig. 1. An example of the determination of the fire-integrated emission ratio for an open wood cooking fire by plotting the excess mixing ratios of methanol versus those of $\mathrm{CO}$. The excess methanol is shown as determined by both nonlinear least squares synthetic calibration (NLLS) and spectral subtraction (SS).

The agricultural waste burns took place in two adjacent, $\sim 2$ ha barley fields northwest of Salamanca. The fields had been mechanically harvested so all that remained were standing stalks (stubble, $\sim 15 \mathrm{~cm}$ ) and a mat of broken stalks and chaff, all of it tinder dry. Photographs of many of the field sites described above can be found at http://www.cas.umt.edu/chemistry/faculty/ yokelson/galleries/album_Mex/index.html.

\subsection{Instrumentation}

The primary instrument for measuring trace gas emissions was our mobile, rolling cart-based Fourier transform infrared spectrometer (Fig. 2, Christian et al., 2007). It is rugged, easily transported, optionally self-powered, and can be wheeled to remote sampling sites. The optical bench is isolated from the chassis with wire rope shock absorbers (Aeroflex) and holds a MIDAC 2500 spectrometer, White cell (Infrared Analysis, path length $9 \mathrm{~m}$ ), MCT detector (Graseby), and transfer and focusing optics (Janos Technology). Continuous temperature (Minco) and pressure (MKS) sensors are mounted inside the cell. Other onboard features include a laptop computer, A/D and AC/DC converters, and a 73 amp hour $12 \mathrm{~V}$ battery. Sample air is drawn into the cell by an onboard DC pump through several meters of $0.635 \mathrm{~m}$ o.d. corrugated Teflon tubing. Each sample was held in the cell for one minute using manual Teflon valves while IR spectra were co-added to increase the signal to noise ratio. We used nonlinear least squares, synthetic calibration (Griffith, 2002) to retrieve excess mixing ratios from the spectra for water $\left(\mathrm{H}_{2} \mathrm{O}\right)$, carbon dioxide $\left(\mathrm{CO}_{2}\right)$, carbon monoxide $(\mathrm{CO})$, methanol $\left(\mathrm{CH}_{3} \mathrm{OH}\right)$, methane $\left(\mathrm{CH}_{4}\right)$, ethylene $\left(\mathrm{C}_{2} \mathrm{H}_{4}\right)$, propylene $\left(\mathrm{C}_{3} \mathrm{H}_{6}\right)$, acetylene $\left(\mathrm{C}_{2} \mathrm{H}_{2}\right)$, formaldehyde $(\mathrm{HCHO})$, and hydrogen chloride $(\mathrm{HCl})$. We used spectral subtraction (Yokelson et al., 1997) to retrieve excess mix-

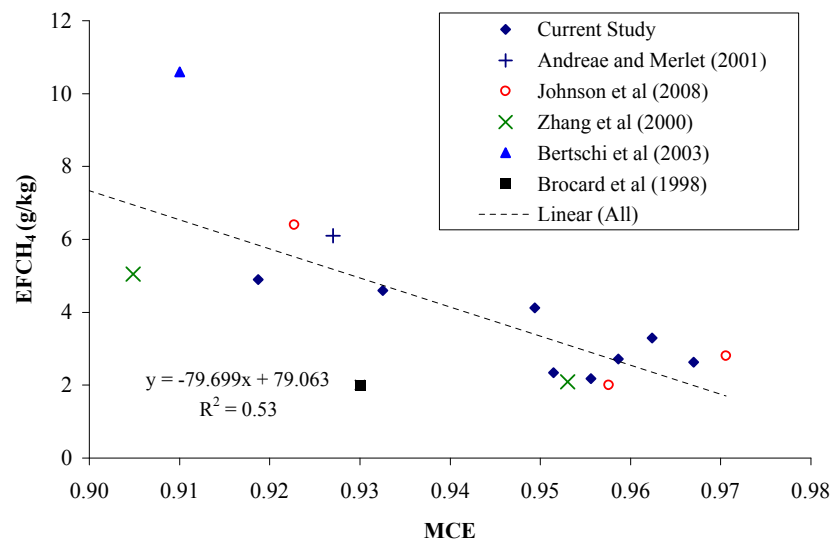

Fig. 2. Variation of the methane emission factor with MCE for open wood cooking fires.

ing ratios for $\mathrm{CH}_{3} \mathrm{OH}, \mathrm{C}_{2} \mathrm{H}_{4}, \mathrm{C}_{3} \mathrm{H}_{6}, \mathrm{C}_{2} \mathrm{H}_{2}$, ammonia $\left(\mathrm{NH}_{3}\right)$, formic acid ( $\mathrm{HCOOH}$, also denoted $\mathrm{HFo})$, and acetic acid $\left(\mathrm{CH}_{3} \mathrm{COOH}\right.$, also $\left.\mathrm{HAc}\right)$. At a path length of $9 \mathrm{~m}$ the detection limit for most gases was $\sim 50-200 \mathrm{ppb}$ while typical analyte mixing ratios were in the thousands of $\mathrm{ppb}$ or larger. The above gases accounted for all the quantifiable features in the IR spectra. The typical uncertainty for mixing ratios was $\pm 10 \%(1 \sigma)$. For $\mathrm{CO}_{2}, \mathrm{CO}$, and $\mathrm{CH}_{4}$, the uncertainties were $3-5 \%$. More complete descriptions of the system and spectral analyses are given in Christian et al. (2007).

After the campaign we checked for changes in analyte concentrations that might occur during the one-minute storage period in the FTIR cell due to adsorption or other reasons (Yokelson et al., 2003). The average $\mathrm{NH}_{3}$ concentration in the cell during one minute of signal averaging (the typical sampling time used in Mexico) was about $71 \%$ of its initial level. The average $\mathrm{HCl}$ was $~ 93 \%$ of its initial level for the same interval. The ammonia and $\mathrm{HCl}$ results reported here have been adjusted upward to account for these cell losses.

A commercial filter-sampling system (Thermo MIE Corp.) with an internal pump ( $3 \mathrm{~L} / \mathrm{min})$ and an impactor was used to collect fire-integrated $\mathrm{PM}_{2.5}$ on quartz filters. Analyses of the quartz filters were performed in the laboratories of the Research Center for Environmental Changes, Academia Sinica, Taipei, Taiwan. Organic and elemental carbon (OC, EC) were determined with a Sunset Laboratory, Inc. continuous carbon analyzer using thermal-optical transmission (Birch and Cary, 1996; Engling et al., 2006). Anhydrosugars (levoglucosan, mannosan, galactosan) were determined using high-performance anion-exchange chromatography with pulsed amperometric detection (HPAEC-PAD). Briefly, a Dionex ICS-3000 ion chromatograph was equipped with an electrochemical detector and a Dionex CarboPak MA1 analytical column $(4 \times 250 \mathrm{~mm})$. Sodium hydroxide solution (400 mM, $0.4 \mathrm{~mL} / \mathrm{min}$ ) was used as eluent. A detailed description of the HPAEC-PAD method can be found elsewhere (Engling et al., 2006, Iinuma et al., 2009). Soluble 
ions were determined with ion chromatography (Hsu et al., 2008b). In brief, a Dionex DX120 ion chromatograph was equipped with a conductivity detector and AS4A and CS12A columns for anion and cation separation, respectively. The eluents used for the respective ion separations were $1.7 \mathrm{mM}$ $\mathrm{NaHCO}_{3}$ and $1.8 \mathrm{mM} \mathrm{Na}_{2} \mathrm{CO}_{3}$ at a flow rate of $1.5 \mathrm{~mL} / \mathrm{min}$ for anions and $20 \mathrm{mM} \mathrm{CH}_{4} \mathrm{O}_{3} \mathrm{~S}$ for cations at a flow rate of $1.0 \mathrm{~mL} / \mathrm{min}$. We analyzed the quartz filters for trace elements using inductively coupled plasma-mass spectrometry (ICPMS) (Hsu et al., 2008a, 2010).

We did not sample particles with Teflon filters, which are used for gravimetric determination of total $\mathrm{PM}_{2.5}$. However, we did deploy an integrating nephelometer (Radiance Research M903) that measured particle light-scattering at $530 \mathrm{~nm}$ and $1 \mathrm{~Hz}$. The nephelometer was calibrated with particle free zero air and $\mathrm{CO}_{2}$ before and after the campaign. The M903 nephelometer response was attenuated at the highest concentrations we encountered in Mexico. Thus, we applied a correction factor to those high values based on direct comparison in laboratory smoke between the M903 and a TSI 3563 nephelometer, which does have a sufficiently large linear range. The M903 nephelometer output $\left(b_{\text {scat }}, \mathrm{m}^{-1}\right)$ has been compared directly to gravimetric $\mathrm{PM}_{2.5}$ determinations on cooking fires in both Honduras (Roden et al., 2006) and Mexico (Brauer et al., 1996). For dry, fine particles the conversion factor depends mostly on the EC/OC ratio of the particles. Our average EC/OC ratio (0.284) for cooking fires was very close to that reported by Roden et al. (2006) for their cooking fires $(0.267)$. Thus, we used the average of the two conversion factors from the other cooking fire studies to convert light-scattering data from our cooking fires to an estimated total $\mathrm{PM}_{2.5}$ as follows:

$b_{\text {scat }}(530 \mathrm{~nm}, 273 \mathrm{~K}, 1 \mathrm{~atm}) \times 552000 \pm 75000$

$=\mathrm{PM}_{2.5}\left(\mu \mathrm{g} / \mathrm{m}^{3}, 273 \mathrm{~K}, 1 \mathrm{~atm}\right)$

(The conversion factor is equivalent to a mass scattering efficiency of 1.8). This approach probably gives an uncertainty in our average $\mathrm{PM}_{2.5}$ for cooking fires of about $20-40 \%$.

The light scattering by the particles from the other combustion types could be very different so we did not estimate a total $\mathrm{PM}_{2.5}$ for these sources from the nephelometer data. However, we do report the mass sum of the particle constituents on the quartz filters. In this sum, we multiply the OC by a conservative factor of 1.4 to account for non-carbon organic mass (Aiken et al., 2008). The species measured include most of the major particulate components with the exception of sulfate and ammonium, which accounted for only a few percent of particle mass in other Mexican biomass burning particles (Yokelson et al., 2009). Thus, the sum of detected species is likely not more than $10-30 \%$ lower than the total $\mathrm{PM}_{2.5}$.

We also deployed $\mathrm{COO}_{2}$ instrument (LICOR LI-7000) that was calibrated both before and after the campaign (negligible drift) with NIST-traceable standards spanning the $\mathrm{CO}_{2}$ range encountered in the field. The $\mathrm{CO}_{2}$, nephelometer, and filter sampling systems shared a single inlet (conductive silicon tubing) that was often co-located with the FTIR sample line. In the cases where the FTIR mobility allowed sampling of the emissions at more points than the other instruments, the accurate determination of $\mathrm{CO}_{2}$ by both the LICOR and the FTIR allowed coupling the two data sets. $\mathrm{CO}_{2}$ was also used to correlate the particle measurements to the trace gases measured by FTIR as described in detail elsewhere (Yokelson et al., 2009; Yokelson et al., 2007).

\subsection{Calculation of emission ratios and emission factors}

An emission ratio (ER) is defined as the initial molar excess mixing ratio (EMR) of one species divided by that of another species, most commonly $\mathrm{CO}$ or $\mathrm{CO}_{2}$. EMR is simply the molar amount of a species above the background level and is designated with the Greek capital delta - e.g. $\Delta \mathrm{CO}$, $\Delta \mathrm{CH}_{4}, \Delta \mathrm{X}$, etc. Modified combustion efficiency (MCE) is defined as the ratio $\Delta \mathrm{CO}_{2} /\left(\Delta \mathrm{CO}_{2}+\Delta \mathrm{CO}\right)$ and is useful for estimating the relative amounts of flaming and smoldering combustion during a fire, with high MCE corresponding to more flaming (Ward and Radke, 1993). To estimate the fireaverage ER for a species " $\mathrm{X}$ " we plot $\Delta \mathrm{X}$ for all the samples of the fire versus the simultaneously measured $\triangle \mathrm{CO}$ (or $\left.\Delta \mathrm{CO}_{2}\right)$ and fit a least squares line with the intercept forced to zero. The slope is taken as the best estimate of the ER as explained in more detail in Yokelson et al. (1999). Figure 1 is an example of this type of plot showing the $\mathrm{CH}_{3} \mathrm{OH} / \mathrm{CO}$ ER derived from 10 FTIR samples obtained over the course of a wood cooking fire.

An emission factor for any species " $\mathrm{X}$ " (EFX) is the mass of species X emitted per unit mass of dry fuel burned ( $\mathrm{g}$ compound per kg dry fuel). EF can be derived from a set of molar ER to $\mathrm{CO}_{2}$ using the carbon mass balance method, which assumes that all of the burned carbon is volatilized and that all of the major carbon-containing species have been measured. It is also necessary to measure or estimate the carbon content of the fuel. For the fires using biomass fuel we assumed a dry, ash-free carbon content of $50 \%$ by mass (Susott et al., 1996). For the garbage fires, which contained only some biomass, we estimated the relative abundance of the materials present from photographs. We then calculated the overall carbon fraction based on those proportions and carbon content estimates for each type of material (IPCC, 2006; USEPA, 2007). Table 2 shows that this procedure resulted in an overall carbon fraction of $40 \%$ for the landfill materials. The EF calculations for a charcoal kiln are complex because the fuel carbon fraction increases with time. We used a procedure identical to that described in detail by Bertschi et al. (2003).

$\mathrm{EFPM}_{2.5}$ for the cooking fires were calculated by multiplying the fire-integrated $\mathrm{PM}_{2.5}$ to $\mathrm{CO}_{2}$ mass ratio $\left(g \mathrm{PM}_{2.5} / g \mathrm{CO}_{2}\right.$ as measured by the nephelometer and LICOR $)$ by the $\mathrm{EFCO}_{2}\left(g \mathrm{CO}_{2} / \mathrm{kg}\right.$ dry fuel as measured by 
Table 2. Estimate of the carbon content of Mexican peri-urban landfills.

\begin{tabular}{lccc}
\hline Category & $\begin{array}{c}\text { Relative proportion } \\
\text { by volume }\end{array}$ & $\begin{array}{c}\text { Estimated } \\
\text { mass fraction }^{\mathrm{b}}{ }^{\mathrm{b}}\end{array}$ & $\begin{array}{c}\text { Carbon } \\
\text { fraction }^{\mathrm{c}}\end{array}$ \\
\hline plastic & 0.65 & 0.30 & 0.74 \\
paper & 0.10 & 0.15 & 0.46 \\
organic (food waste) & 0.05 & 0.05 & 0.38 \\
textile/synthetic fiber & 0.05 & 0.05 & 0.60 \\
rubber/leather & 0.05 & 0.05 & 0.76 \\
glass & 0.02 & 0.05 & \\
vegetation & 0.01 & 0.05 & 0.50 \\
metal & 0.01 & 0.05 & \\
ceramic & 0.01 & 0.05 & \\
other & 0.05 & 0.20 & \\
\hline net & 1.00 & 1.00 & $40 \%$ \\
\hline
\end{tabular}

a Visual estimate of relative volumes of the most prominent waste materials from four Mexican landfills. $b$ Rough estimate of relative mass for each material type. ${ }^{\mathrm{c}}$ Combined estimates from IPCC (2006) Table 2.4 and USEPA (2007) Annex 3 Tables A-125 to A-130.

FTIR). A similar method was applied to individual particle species based on net mass loading of fire-integrated filters, volumetric flow, and $\mathrm{EFCO}_{2}$.

\section{Results and discussion}

\subsection{Cooking fires}

Trace gas ER and EF and particle EF based on light scattering for our cooking fires are given in Table 3. The first 10 columns of data are the eight open wood cooking fires plus a column each for the average and standard deviation. The next three columns are the EF and average for the two Patsari stoves as sampled in the kitchen. The last three columns are the analogous data from the outdoor chimney exhaust of the same two Patsari stoves. The EF for individual particle species measured on the quartz filters are given for all the fires in Table 4. Open wood cooking fires are the main global type of biofuel use and we get an idea of the global variability in this source by comparing EF from selected studies for some of the more commonly measured emissions $\left(\mathrm{CO}_{2}, \mathrm{CO}, \mathrm{CH}_{4}\right.$, and $\left.\mathrm{PM}\right)$.

Figure 2 shows $\mathrm{EFCH}_{4}$ versus MCE (a function of $\mathrm{CO}$ and $\mathrm{CO}_{2}$ ) for those studies, including this one, where $\mathrm{CO}$, $\mathrm{CO}_{2}$, and $\mathrm{CH}_{4}$ data were all available. A range of MCE from about 0.90 to 0.98 (avg 0.946 ) occurs naturally for individual fires in these studies. This leads to about a factor of 10 variation in $\mathrm{EFCH}_{4}$ for individual fires, but the studyaverage values agree reasonably well with each other. Some notes about the studies included in Fig. 2 follow. The Johnson et al. (2008) study was conducted in the same villages in Michoacán where the majority of our cooking fires were sampled. The authors sampled eight open cooking fires and

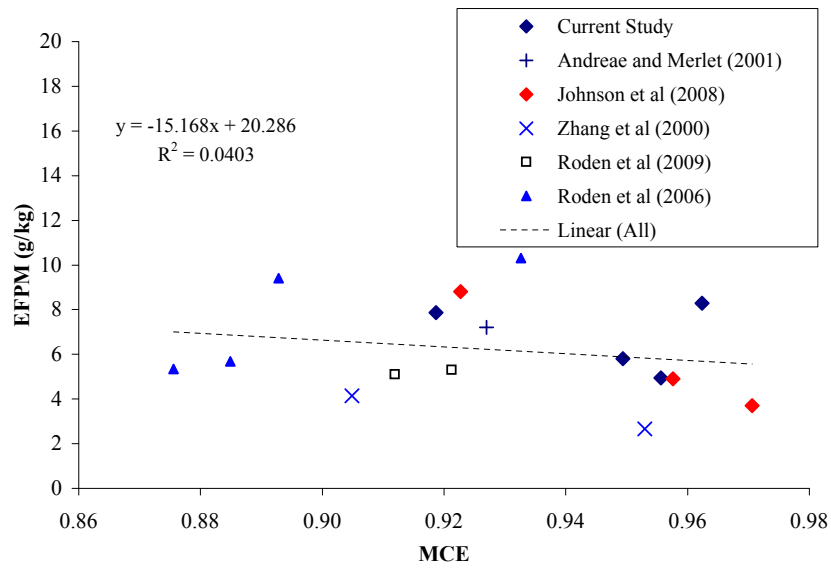

Fig. 3. Variation of the particle emission factor with MCE for open wood cooking fires. (This work and Andreae and Merlet 2001 $\mathrm{PM}_{2.5}$, Roden et al. (2006) - $\mathrm{PM}_{4}$, all others TPM).

13 Patsari stoves and reported fire-integrated trace gas emission factors based on gas chromatographic analysis of smoke collected in Tedlar bags over the course of each fire. Zhang et al. (2000) set up a simulated kitchen in China and, using similar sampling methods as Johnson et al., reported fireintegrated emissions from a few open stove types with various common fuels. The Zhang et al. (2000) data in Fig. 2 include only their wood and brush fuel types. Bertschi et al. (2003) reported the average EF for 3 open wood cooking fires in a village in Zambia. Brocard et al. (1996) reported the average EF for 43 open wood cooking fires on the Ivory Coast. The Andreae and Merlet (2001) data point is a widely-used global estimate derived from the literature. The Bertschi et al. (2003) $\mathrm{EFCH}_{4}$ appears higher than the trend and the Brocard et al. (1996) $\mathrm{EFCH}_{4}$ lower, but these data are consistent with a tendency toward greater variability as the relative amount of smoldering emissions increases in biomass burning fires (Christian et al., 2007; Yokelson et al., 2008).

Particle EF also vary substantially as seen in Fig. 3, which includes EFPM from three of the same studies that are included in Fig. 2 (Andreae and Merlet, 2001; Johnson et al., 2008; Zhang et al., 2000), as well as two other relevant studies (Roden et al., 2006, 2009). Roden et al. used a combination of nephelometry, absorption photometry, filter collection, and $\mathrm{CO} / \mathrm{CO}_{2}$ instrumentation to measure real-time and fire-integrated EF from 56 fires in various stove types in rural Honduran homes, and 14 laboratory simulations in several stove types. Figure 3 incorporates only their data from 6 traditional, open wood cooking fires in homes. $\left(\mathrm{CO}_{2}\right.$ data for calculating MCE for the two Roden et al. $(2006,2009)$ studies were kindly provided by the authors.) Again there is considerable variability in EF for individual fires, but reasonable agreement between authors on the range and average. This body of work on PM suggests a slightly lower 
Table 3. Normalized emission ratios (ER, mol/mol) and emission factors (EF, g/kg dry fuel) for 8 open wood cooking fires and 2 Patsari stoves in central Mexico.

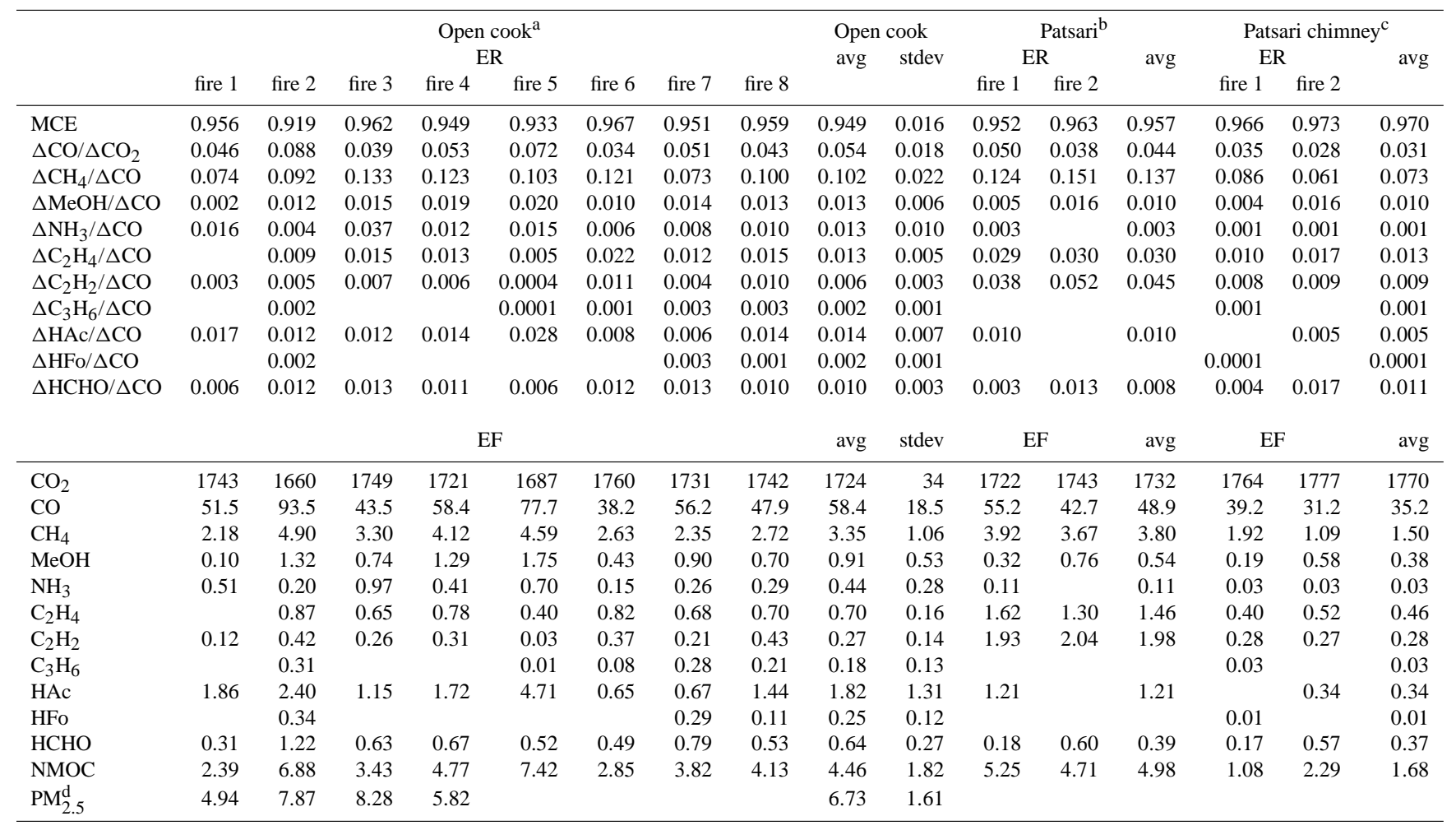

a 161 background and indoor sample measurements of nascent smoke from open wood cooking fires in 7 kitchens (fires 1-7) and the GIRA lab (fire 8). b 14 background and indoor sample measurements directly above the fire box of the Patsari stove in the GIRA lab (fire 1) and 1 kitchen (fire 2). ${ }^{\mathrm{c}} 26$ outdoor background and sample measurements at the chimney outlet of the same 2 Patsari stoves. ${ }^{\mathrm{d}} \mathrm{PM}_{2.5}$ measurements were continuous at a sampling frequency of 1-2 Hz MeOH - methanol; HAc - acetic acid; HFo - formic acid; NMOC - the sum of non-methane organic compounds measured by FTIR.

average MCE (0.928) than implied in Fig. 2. If we assume a global average MCE in the range $\sim 0.93-0.94$, then the trendlines imply global average EF for open wood cooking fires of $4.5 \pm 1.4 \mathrm{~g} / \mathrm{kg}$ for $\mathrm{CH}_{4}$ and $6.1 \pm 2.7 \mathrm{~g} / \mathrm{kg}$ for PM. A larger uncertainty in global average $\mathrm{EF}$ would result by considering more of the less common fuels (agricultural waste, dung, etc) and stove types.

For compounds that are major open cooking fire emissions, but difficult to measure by non-spectroscopic methods $\left(\mathrm{CH}_{3} \mathrm{COOH}, \mathrm{NH}_{3}, \mathrm{HCHO}, \mathrm{CH}_{3} \mathrm{OH}, \mathrm{HCOOH}\right)$, we can compare our current EF from Mexico only to those obtained by open-path FTIR on African open wood cooking fires by Bertschi et al. (2003). The Bertschi et al. (2003) EF were measured at a lower average MCE (0.91) than the average MCE for our fires in Mexico (0.95) and thus, not surprisingly the $\mathrm{EF}$ for the smoldering compounds (most of the gases measured excluding $\mathrm{CO}_{2}$ and $\mathrm{NO}_{x}$ ) in Bertschi et al. are generally about 2-4 times higher. Averaging the results from these two FTIR-based studies is consistent with the average MCE for cooking fires of $\sim 0.93$ derived above.
As mentioned above, the use of improved stoves with chimneys and insulated fire boxes reduces both the total biofuel emissions (due to reduced fuel consumption) and the indoor air pollution. There is also potential for improved stoves to consume the fuel at higher MCE, reducing the EF for smoldering compounds. A further possibility is that the surface of the chimney could scavenge some of the more reactive smoke components before they are emitted to the airshed. To examine these issues we compare the average MCE and $\mathrm{EF}$ of the Patsari chimney exhaust to the average MCE and EF for the open fire emissions. The average MCE was lower from our open fires $(\sim 0.95)$ than it was from our Patsari chimney exhaust (0.97). Consistent with the increased Patsari MCE, the EF for $\mathrm{CO}, \mathrm{CH}_{4}$, and the measured NMOC (with the exception of organic acids, $\mathrm{C}_{3} \mathrm{H}_{6}$, and $\mathrm{C}_{2} \mathrm{H}_{2}$ ) were about a factor of two lower from the chimney exhaust. For organic acids, $\mathrm{NH}_{3}$, and $\mathrm{C}_{3} \mathrm{H}_{6}$ there was a larger drop (8095\%) in the EF measured from the chimneys that was likely due in large part to losses on the chimney walls. $\mathrm{EFC}_{2} \mathrm{H}_{2}$ is similar for both sources as it is emitted by both flaming 
Table 4. Emission factors (EF, $\mathrm{g} / \mathrm{kg}$ fuel) for individual particle species ${ }^{\mathrm{a}}$.

\begin{tabular}{|c|c|c|c|c|c|c|c|c|c|c|c|c|c|}
\hline & $\begin{array}{c}\text { Open } \\
\text { cook } \\
\text { (fire 2) }\end{array}$ & $\begin{array}{c}\text { Open } \\
\text { cook } \\
\text { (fire 3) }\end{array}$ & $\begin{array}{l}\text { Open } \\
\text { cook } \\
\text { (fire 4) }\end{array}$ & $\begin{array}{c}\text { Open } \\
\text { cook } \\
\text { (fire 5) }\end{array}$ & $\begin{array}{c}\text { Open } \\
\text { cook } \\
\text { (fire 6) }\end{array}$ & $\begin{array}{c}\text { Garbage } \\
\text { (fire 2) }\end{array}$ & $\begin{array}{c}\text { Garbage } \\
\text { (fire 3) }\end{array}$ & $\begin{array}{c}\text { Garbage } \\
\text { (fire 4) }\end{array}$ & $\begin{array}{c}\text { Brick } \\
\text { kiln } \\
\text { (fire 1) }\end{array}$ & $\begin{array}{c}\text { Brick } \\
\text { kiln } \\
\text { (fire 2) }\end{array}$ & $\begin{array}{c}\text { Charcoal } \\
\text { kiln } \\
\text { (day 3) }\end{array}$ & $\begin{array}{l}\text { Charcoal } \\
\text { kiln } \\
\text { (day 4) }\end{array}$ & $\begin{array}{c}\text { Stubble } \\
\text { burn } \\
\text { (fire 1) }\end{array}$ \\
\hline & \multicolumn{13}{|c|}{ TOT (Thermal Optical Transmission) } \\
\hline OC & 3.77 & 1.39 & 2.46 & 1.43 & 1.19 & 10.9 & 2.13 & 2.78 & 0.073 & 0.283 & 0.382 & 1.10 & 5.92 \\
\hline EC & 0.355 & 0.480 & 0.667 & 0.205 & 0.674 & 0.381 & 0.924 & 0.634 & 0.596 & 1.50 & 0.007 & 0.031 & 0.055 \\
\hline $\mathrm{EC} / \mathrm{OC}$ & 0.094 & 0.345 & 0.271 & 0.143 & 0.568 & 0.035 & 0.434 & 0.228 & 8.15 & 5.29 & 0.018 & 0.028 & 0.009 \\
\hline \multicolumn{14}{|c|}{ HPAEC (High Performance Anion Exchange Chromatography) } \\
\hline Levoglucosan & 0.901 & 0.124 & 0.202 & 0.111 & 0.110 & 0.346 & 0.290 & 0.102 & 0.0004 & 0.002 & 0.008 & 0.119 & 0.712 \\
\hline Mannosan & 0.387 & 0.010 & 0.013 & 0.017 & 0.033 & 0.026 & 0.011 & 0.004 & & 0.0004 & 0.001 & 0.007 & 0.015 \\
\hline Galactosan & 0.180 & 0.004 & 0.006 & 0.008 & 0.008 & 0.007 & 0.001 & & & & 0.001 & 0.006 & 0.028 \\
\hline \multicolumn{14}{|c|}{ IC (Ion Chromatography) } \\
\hline $\mathrm{K}^{+}$ & 0.0212 & 0.0296 & 0.0415 & 0.0234 & 0.0151 & 0.0352 & 0.0163 & 0.0129 & 0.0053 & 0.0052 & 0.0060 & 0.0030 & 0.2799 \\
\hline $\mathrm{Ca}^{2+}$ & 0.0056 & 0.0144 & 0.0013 & & 0.0001 & 0.0013 & 0.0011 & 0.0004 & 0.0001 & 0.0014 & & & \\
\hline $\mathrm{Cl}^{-}$ & 0.0088 & 0.0109 & 0.0066 & 0.0038 & 0.0063 & 1.03 & 0.17 & 0.20 & 0.5085 & 0.0538 & 0.0024 & 0.0706 & 0.7207 \\
\hline $\mathrm{NO}_{3}^{-}$ & 0.0078 & 0.0074 & 0.0115 & 0.0034 & 0.0033 & & & & 0.0004 & 0.0017 & 0.0007 & & 0.0065 \\
\hline \multicolumn{14}{|c|}{ ICP-MS (Inductively Coupled Plasma Mass Spectroscopy) } \\
\hline $\mathrm{Fe}$ & & & & & & & & & 0.00859 & & & & \\
\hline $\mathrm{Na}$ & & & & & & 0.06937 & 0.01848 & 0.02067 & 0.00797 & & & & 0.12498 \\
\hline $\mathrm{Mg}$ & 0.01038 & 0.02676 & 0.00778 & & 0.00232 & 0.09713 & & 0.01160 & & & & & \\
\hline $\mathrm{K}$ & 0.03843 & 0.07388 & 0.06657 & & 0.02309 & & 0.03202 & & & & & & 0.67046 \\
\hline $\mathrm{Ca}$ & 0.02657 & 0.09759 & 0.02257 & 0.02244 & 0.00486 & 0.32613 & & 0.03058 & & & 0.00709 & & \\
\hline $\mathrm{Sr}$ & 0.00036 & 0.00110 & 0.00024 & & 0.00008 & 0.00280 & & 0.00031 & 0.00007 & 0.00010 & & & \\
\hline $\mathrm{Ti}$ & 0.00108 & 0.00223 & & & & 0.00452 & & & & 0.00065 & & & \\
\hline $\mathrm{Mn}$ & & 0.00063 & & & & & & & & 0.00016 & & & \\
\hline Co & 0.00004 & 0.00006 & & & 0.00002 & & & & 0.00006 & & 0.00011 & & \\
\hline $\mathrm{Ni}$ & & & & & & & & & & & & 0.00057 & \\
\hline $\mathrm{Cu}$ & 0.00040 & 0.00042 & & 0.00035 & & 0.00213 & 0.00035 & 0.00074 & 0.00465 & 0.00017 & 0.00043 & 0.00096 & \\
\hline $\mathrm{Zn}$ & 0.00078 & 0.00081 & & & 0.00052 & & 0.00098 & 0.00172 & 0.00066 & 0.00112 & & & \\
\hline $\mathrm{Cd}$ & 0.00002 & & & & 0.00001 & 0.00027 & 0.00059 & 0.00053 & 0.00002 & & & & \\
\hline $\mathrm{Sn}$ & 0.00002 & & & & & 0.00199 & 0.00345 & 0.00410 & 0.00003 & 0.00006 & & & 0.00009 \\
\hline $\mathrm{Sb}$ & 0.00001 & 0.00007 & 0.00001 & 0.00001 & 0.00000 & 0.00212 & 0.01872 & 0.01154 & 0.00002 & 0.00004 & 0.000005 & & 0.00003 \\
\hline $\mathrm{Pb}$ & & & & & 0.00003 & 0.00400 & 0.00780 & 0.00460 & 0.00026 & 0.00023 & & & \\
\hline $\mathrm{V}$ & 0.00008 & 0.00012 & 0.00002 & & 0.00003 & 0.00020 & 0.00001 & 0.00002 & 0.00004 & 0.00003 & 0.00010 & 0.00005 & 0.00014 \\
\hline $\mathrm{Cr}$ & & 0.00156 & & & & & & & & & & 0.00350 & \\
\hline As & 0.00004 & 0.00007 & 0.00010 & 0.00004 & 0.000002 & 0.00287 & 0.00003 & 0.00029 & 0.00002 & 0.00003 & 0.00005 & 0.00023 & 0.00033 \\
\hline $\mathrm{Rb}$ & 0.00022 & 0.00027 & 0.00031 & 0.00013 & 0.00007 & 0.00021 & 0.00003 & 0.00004 & 0.00002 & 0.00003 & 0.00002 & 0.00009 & 0.00037 \\
\hline Sum $^{b}$ & 5.75 & 2.69 & 4.27 & 2.27 & 2.39 & 17.22 & 4.17 & 4.82 & 1.24 & 1.96 & 0.56 & 1.65 & 10.14 \\
\hline
\end{tabular}

${ }^{a}$ Data set is limited to those fires for which we collected quartz filters. ${ }^{b}$ Sum of masses, excluding anhydrosugars, with OC multiplied by 1.4 to account for non-carbon organic mass.

and smoldering (Yokelson et al., 2008) and is not particularly "sticky". Overall, while only a fraction of the total NMOC emitted could be measured (Yokelson et al., 2008), the sum of the EFNMOC that were measured in this study from the chimney was $\sim 38 \%$ of the analogous sum from the open fires. We were unable to measure particle EF from the Patsari chimney. Johnson et al. (2008) also compared EF for open fires to EF for Patsari stoves in their Table 1 (bottom 3 rows). Their data show an increase in MCE from 0.92 (open) to 0.98 (Patsari). They also reported a large reduction in the EF for $\mathrm{CO}, \mathrm{CH}_{4}$, and $\mathrm{PM}$, which was variable depending on the type of Patsari stove sampled. Based on the above, it appears that improved stoves could reduce both fuel consumption (by about half, Masera et al., 2005) and the amount of many pollutants emitted per unit mass of fuel consumed (by at least half). The homes that we sampled in were well-ventilated, but some scavenging of reactive species may occur on the walls. There have been no attempts to measure the extent of this to our knowledge.

There is a noticeable absence in Table 3 of $\mathrm{HCN}$, which is widely used as a biomass burning tracer (Yokelson et al., 2007). HCN is normally well above the detection limits of our FTIR systems for landscape-scale biomass burning (e.g. forest fires, grass fires, Yokelson et al., 2007). However, HCN was below our FTIR detection limits for cooking fires in both Africa (Bertschi et al., 2003) and Mexico (current study). A single FTIR sample from a Brazilian stove (Christian et al., 2007) did contain some HCN, but the ER to $\mathrm{CO}(0.0005)$ was $\sim 24$ times lower than the value for Mexico City area forest fires (0.012, Yokelson et al., 2007). The low HCN/CO ER for cooking fires means that where these fires are common, the biomass burning contribution to total 
pollution will be underestimated if it is based on an $\mathrm{HCN} / \mathrm{CO}$ ER appropriate for landscape-scale burning (Yokelson et al., 2007).

Acetonitrile is another useful biomass burning tracer (de Gouw et al., 2001), but cooking fire measurements for this species have not been attempted yet. However, since acetonitrile emissions from other types of biomass burning are usually less than half the HCN emissions (Yokelson et al., 2009), they may also be unusually small from cooking fires. Methyl chloride $\left(\mathrm{CH}_{3} \mathrm{Cl}\right)$ has also been linked to biomass burning (Lobert et al., 1991), but its emissions are probably much smaller from cooking fires than for other types of biomass burning since wood has much lower chlorine content than other components of vegetation (Table 4, Lobert et al., 1999). Levoglucosan and K (in fine particles) are also used as biomass burning indicators and they were observed in "normal" amounts in the particles from our cooking fires (Table 4) compared to other types of biomass burning. However, as discussed in more detail in Sect. 3.2, levoglucosan and $\mathrm{K}$ were also present in similar amounts in the fine particles from garbage burning. Thus, in areas such as central Mexico where garbage burning is common it could contribute a significant fraction of the aerosol levoglucosan or $\mathrm{K}$. The lack of a straightforward chemical tracer for cooking fires is especially significant since these fires will also not be detected from space as hotspots or burned area. In addition, the $\mathrm{CO}$ could be underestimated by MOPITT due to the low injection altitude for cooking fire smoke (Emmons et al., 2004) and the short (one-month) lifetime for CO in the tropics. Thus, biomass burning estimates based on $\mathrm{HCN}$ or acetonitrile likely underestimate cooking fires (and total biomass burning), while estimates based on levoglucosan or K could be subject to "interference" from garbage burning in parts of the developing world. In summary, while survey-based research clearly indicates that biofuel use is the second-largest global type of biomass burning, there is not a simple chemical tracer to confirm this or to independently determine the amount of biofuel use embedded in urban areas of the developing world.

\subsection{Garbage burning}

Our ER and EF for trace gases emitted by garbage burning are shown for individual fires in the left half of Table 5. Garbage fire 2 had already progressed to mostly smoldering combustion when we arrived. At the other three fires we sampled mostly flaming. Since we don't know the real overall ratio of flaming to smoldering combustion for landfill fires we just calculated the straight average and the standard deviation for all four fires. For the trace gas EF this is equivalent to assuming that $\sim 75 \%$ of the fuel is consumed by flaming combustion and the remainder by smoldering. The EF are computed assuming the waste in these landfills was $40 \% \mathrm{C}$ by mass. If the \% $\mathrm{C}$ is higher or lower the real $\mathrm{EF}$ would be higher or lower in direct proportion. It is important to note, however, that the ER to $\mathrm{CO}$ or $\mathrm{CO}_{2}$ are independent of any assumptions about the composition of the fuel. The EF for particle species are included in Table 4. Since we only have filter data for two flaming and one smoldering garbage fire, an average of the filter results is equivalent to assuming that two-thirds of the fuel was consumed by flaming.

We could not find any published, peer-reviewed, direct emissions measurements from open burning in landfills to compare our results to. Data from airborne and ground-based measurements of aerosols over the east Asian Pacific as part of ACE-Asia (Simoneit et al., 2004a, 2004b) revealed significant levels of phthalates and n-alkanes in the aerosols. The presence of these compounds was attributed to refuse burning. A follow up study confirmed these compounds as major organic constituents in both solvent extracts of common plastics and the aerosols generated by burning the same plastics in the laboratory (Simoneit et al., 2005). This indicated their potential usefulness as tracers. However, these are high molecular weight, semi- or non-volatile compounds whose relationship to volatile gaseous emissions is not known.

The comparison of the garbage burning emissions to biomass burning emissions is interesting. The average ethylene molar ER to $\mathrm{CO}$ for garbage burning $\left(\Delta \mathrm{C}_{2} \mathrm{H}_{4} / \Delta \mathrm{CO}\right.$, 0.044 ) is 3-4 times higher than for our open wood cooking fires (0.013, Table 3) or forest fires near Mexico City (0.011, Yokelson et al., 2007) and is likely a result of burning a high proportion of ethylene-based plastic polymer fuels.

$\mathrm{HCl}$ is not commonly detected from biomass burning (Lobert et al., 1999), but the EFHCl in the garbage burning emissions ranged from 1.65 to $9.8 \mathrm{~g} / \mathrm{kg}$, a range similar to that for $\mathrm{CH}_{4}$ in biomass burning emissions. Lemieux et al. (2000) reported a strong dependence on polyvinyl chloride (PVC) content for $\mathrm{HCl}$ emissions from simulations of domestic waste burning in barrels. Their EFHCl was $2.40 \mathrm{~g} / \mathrm{kg}(n=2)$ for waste containing $4.5 \%$ PVC by mass, and $0.28 \mathrm{~g} / \mathrm{kg}(n=2)$ for waste with only $0.2 \%$ PVC. There was no mention of precautions taken to avoid passivation losses on sample lines, etc. (e.g. Yokelson et al., 2003). In the current study, significant additional chlorine was present in the particles; EF for soluble $\mathrm{Cl}^{-}$alone ranged from $\sim 0.2$ to $1.03 \mathrm{~g} / \mathrm{kg}$ fuel (Table 4). Studies of landfills in the European Union found that the chlorine content of solid waste was about $9 \mathrm{~g} / \mathrm{kg}$ (Mersiowsky et al., 1999) and that essentially all the chlorine was present as polyvinyl chloride (Costner, 2005), which is $57 \% \mathrm{Cl}$ by mass. We found that burning "pure" PVC in our laboratory produced $\mathrm{HCl} / \mathrm{CO}$ in molar ratios ranging from 5:1 to 10:1. Thus, the observed molar ER for HCl/CO in the MCMA landfill fires (0.037-0.19) are consistent with the burning materials we sampled containing $\sim 0.4-4 \%$ PVC. Our results also suggest that the majority of the chlorine in burning $\mathrm{PVC}$ is emitted as $\mathrm{HCl}$.

Even though the average EC/OC ratio for garbage burning $(0.232, n=3)$ is close to that for the cooking fires $(0.284$, $n=5$ ), application of the cooking fire conversion factor to the garbage burning light scattering data underestimates the 
Table 5. Normalized emission ratios (ER, mol/mol) and emission factors (EF, g/kg dry fuel) ${ }^{\mathrm{a}}$ for 4 garbage fires, 3 brick-making kilns, and 2 barley stubble burns in central Mexico.

\begin{tabular}{|c|c|c|c|c|c|c|c|c|c|c|c|c|c|c|}
\hline & \multicolumn{6}{|c|}{ Garbage burning ${ }^{b}$} & \multicolumn{5}{|c|}{ Brick kilns $^{c}$} & \multicolumn{3}{|c|}{ Stubble burns ${ }^{\mathrm{d}}$} \\
\hline & \multicolumn{4}{|c|}{ ER } & \multirow[t]{2}{*}{ avg } & \multirow[t]{2}{*}{ stdev } & \multicolumn{3}{|c|}{ ER } & \multirow[t]{2}{*}{ avg } & \multirow[t]{2}{*}{ stdev } & \multicolumn{2}{|c|}{ ER } & \multirow[t]{2}{*}{ avg } \\
\hline & fire 1 & fire 2 & fire 3 & fire 4 & & & fire 1 & fire 2 & fire 3 & & & fire 1 & fire 2 & \\
\hline MCE & 0.964 & 0.911 & 0.958 & 0.968 & 0.950 & 0.026 & 0.952 & 0.974 & 0.978 & 0.968 & 0.014 & 0.910 & 0.882 & 0.896 \\
\hline$\Delta \mathrm{CO} / \Delta \mathrm{CO}_{2}$ & 0.038 & 0.098 & 0.044 & 0.033 & 0.053 & 0.030 & 0.050 & 0.027 & 0.023 & 0.033 & 0.015 & 0.099 & 0.134 & 0.116 \\
\hline$\Delta \mathrm{CH}_{4} / \Delta \mathrm{CO}$ & 0.060 & 0.228 & 0.099 & 0.067 & 0.114 & 0.078 & 0.068 & 0.098 & 0.077 & 0.081 & 0.016 & 0.089 & 0.087 & 0.088 \\
\hline$\Delta \mathrm{MeOH} / \Delta \mathrm{CO}$ & 0.008 & 0.031 & 0.009 & 0.008 & 0.014 & 0.011 & 0.022 & & 0.013 & 0.018 & & 0.032 & 0.016 & 0.024 \\
\hline$\Delta \mathrm{NH}_{3} / \Delta \mathrm{CO}$ & 0.023 & 0.052 & 0.017 & & 0.031 & 0.019 & 0.001 & 0.0004 & 0.001 & 0.001 & 0.0003 & 0.025 & 0.035 & 0.030 \\
\hline$\Delta \mathrm{C}_{2} \mathrm{H}_{4} / \Delta \mathrm{CO}$ & 0.024 & 0.060 & 0.057 & 0.033 & 0.044 & 0.018 & 0.005 & 0.011 & 0.014 & 0.010 & 0.005 & 0.015 & 0.018 & 0.017 \\
\hline$\Delta \mathrm{C}_{2} \mathrm{H}_{2} / \Delta \mathrm{CO}$ & 0.004 & 0.010 & 0.015 & 0.007 & 0.009 & 0.004 & 0.0004 & 0.003 & 0.007 & 0.004 & 0.003 & 0.002 & 0.003 & 0.002 \\
\hline$\Delta \mathrm{C}_{3} \mathrm{H}_{6} / \Delta \mathrm{CO}$ & 0.007 & 0.028 & 0.017 & 0.008 & 0.015 & 0.010 & 0.003 & & 0.004 & 0.004 & & 0.005 & & 0.005 \\
\hline$\Delta \mathrm{HAc} / \Delta \mathrm{CO}$ & 0.008 & 0.044 & 0.011 & 0.012 & 0.019 & 0.017 & 0.002 & & & 0.002 & & 0.042 & 0.022 & 0.032 \\
\hline$\Delta \mathrm{HFo} / \Delta \mathrm{CO}$ & 0.011 & 0.002 & 0.011 & 0.008 & 0.008 & 0.004 & 0.0004 & 0.0004 & 0.0005 & 0.0004 & 0.0001 & 0.004 & 0.005 & 0.004 \\
\hline$\Delta \mathrm{HCHO} / \Delta \mathrm{CO}$ & 0.015 & 0.006 & 0.016 & 0.024 & 0.015 & 0.008 & 0.001 & 0.002 & 0.001 & 0.001 & 0.0001 & 0.023 & 0.017 & 0.020 \\
\hline \multirow[t]{2}{*}{$\Delta \mathrm{HCl} / \Delta \mathrm{CO}$} & 0.037 & & 0.194 & 0.078 & 0.103 & 0.081 & & & & & & & & \\
\hline & \multicolumn{4}{|c|}{$\mathrm{EF}$} & avg & stdev & & $\mathrm{EF}$ & & avg & stdev & \multicolumn{2}{|c|}{$\mathrm{EF}$} & avg \\
\hline $\mathrm{CO}_{2}$ & 1404 & 1270 & 1385 & 1409 & 1367 & 65 & 1736 & 1780 & 1787 & 1768 & 28 & 1628 & 1577 & 1602 \\
\hline $\mathrm{CO}$ & 33.8 & 79.1 & 38.7 & 29.6 & 45.3 & 22.8 & 55.7 & 30.2 & 25.7 & 37.2 & 16.2 & 102 & 135 & 118 \\
\hline $\mathrm{CH}_{4}$ & 1.16 & 10.3 & 2.18 & 1.14 & 3.70 & 4.44 & 2.16 & 1.69 & 1.13 & 1.66 & 0.51 & 5.17 & 6.73 & 5.95 \\
\hline $\mathrm{MeOH}$ & 0.31 & 2.81 & 0.40 & 0.26 & 0.94 & 1.25 & 1.42 & & 0.39 & 0.90 & & 3.70 & 2.45 & 3.08 \\
\hline $\mathrm{NH}_{3}$ & 0.46 & 2.52 & 0.39 & & 1.12 & 1.21 & 0.03 & 0.01 & 0.01 & 0.02 & 0.01 & 1.54 & 2.83 & 2.18 \\
\hline $\mathrm{C}_{2} \mathrm{H}_{4}$ & 0.82 & 4.75 & 2.20 & 0.99 & 2.19 & 1.82 & 0.26 & 0.32 & 0.37 & 0.32 & 0.05 & 1.51 & 2.48 & 2.00 \\
\hline $\mathrm{C}_{2} \mathrm{H}_{2}$ & 0.14 & 0.72 & 0.53 & 0.20 & 0.40 & 0.28 & 0.02 & 0.09 & 0.16 & 0.09 & 0.07 & 0.17 & 0.32 & 0.25 \\
\hline $\mathrm{C}_{3} \mathrm{H}_{6}$ & 0.36 & 3.34 & 0.97 & 0.36 & 1.26 & 1.42 & 0.28 & & 0.15 & 0.22 & & 0.77 & & 0.77 \\
\hline HAc & 0.58 & 7.40 & 0.92 & 0.78 & 2.42 & 3.32 & 0.21 & & & 0.21 & & 9.15 & 6.49 & 7.82 \\
\hline HFo & 0.11 & 0.30 & 0.71 & 0.40 & 0.38 & 0.25 & 0.03 & 0.02 & 0.02 & 0.02 & 0.01 & 0.60 & 1.10 & 0.85 \\
\hline $\mathrm{HCHO}$ & 0.56 & 0.48 & 0.68 & 0.76 & 0.62 & 0.13 & 0.08 & 0.05 & 0.04 & 0.05 & 0.02 & 2.48 & 2.47 & 2.48 \\
\hline $\mathrm{HCl}$ & 1.65 & & 9.8 & 3.02 & 4.82 & 4.36 & & & & & & & & \\
\hline NMOC & 2.86 & 19.8 & 6.39 & 3.75 & 8.20 & 7.88 & 2.30 & 0.48 & 1.13 & 1.30 & 0.92 & 18.40 & 15.31 & 16.85 \\
\hline
\end{tabular}

${ }^{a}$ See Sect. 2.4 for details specific to EF calculations for garbage burning. ${ }^{b} 72$ spot measurements from garbage burning in 4 landfills. ${ }^{c} 77$ spot measurements from 3 brick making kilns. ${ }^{\mathrm{d}} 23$ spot measurements from 2 barley stubble field burns. MeOH - methanol; HAc - acetic acid; HFo - formic acid; NMOC - the sum of non-methane organic compounds measured by FTIR.

particle mass compared to summing the particle species data. Preliminary work in our lab suggests this could be due to a shift to larger particles in the emissions from burning plastics. We can roughly estimate the $\mathrm{EFPM}_{2.5}$ for garbage burning from the particle species data. The sum of the measured particle components averaged $8.74 \pm 7.35 \mathrm{~g} / \mathrm{kg}$, which, after allowing for unmeasured species, suggests that the $\mathrm{EFPM}_{2.5}$ is about $10.5 \pm 8.8 \mathrm{~g} / \mathrm{kg}$. The average $\mathrm{EFPM}_{2.5}$ reported by Lemieux et al. (2000) for burning recycled and non-recycled waste in barrels was $11.3 \pm 7.5$. The USEPA recommended EFPM for open burning of municipal waste is $8 \mathrm{~g} / \mathrm{kg}$ (AP-42, USEPA, 1995) based on two laboratory studies from the 1960s (Feldstein et al., 1963; Gerstle and Kemnitz, 1967). This may be low since EFPM is typically $\sim 20 \%$ larger than $\mathrm{EFPM}_{2.5}$ for combustion sources. We note that the AP-42 recommendations for $\mathrm{CO}(42 \mathrm{~g} / \mathrm{kg})$ and $\mathrm{CH}_{4}$ $(6.5 \mathrm{~g} / \mathrm{kg})$ are reasonably close to our values of $45.3 \pm 22.8$ and $3.7 \pm 4.4$, respectively. AP-42 also recommends values for $\mathrm{SO}_{2}(0.5 \mathrm{~g} / \mathrm{kg})$ and $\mathrm{NO}_{\mathrm{x}}(3 \mathrm{~g} / \mathrm{kg})$.

The EF for EC, OC, levoglucosan, and $\mathrm{K}$ for garbage burning had a similar range to the EF for these species for the cooking fires. Levoglucosan is produced from the pyrolysis of cellulose and the landfills contain a lower fraction of cellulose than biomass. However, the levoglucosan emissions per unit mass of paper burned can be considerably higher than those from burning some types of biomass (Table $1, \mathrm{Si}-$ moneit et al., 1999). In our data, the average levoglucosan $\mathrm{EF}$ from garbage burning is $85 \%$ of the $\mathrm{EF}$ for cooking fires, which would make it difficult to use levoglucosan to distinguish between these two sources. The other sugars analyzed in this work (mannosan and galactosan) showed more potential promise in this respect as their EF were $~ 90 \%$ lower for garbage burning than for cooking fires. Finally, the garbage burning EF for mannosan was only $\sim 12 \%$ lower than the single mannosan EF measurement for crop residue burning. This tentatively leaves galactosan as the most promising sugar of those we analyzed to indicate general biomass burning in the presence of garbage burning.

The garbage burning EF were the most different from the biomass burning EF for numerous metals. With correction for local soil composition, some of these metals could ultimately offer a useful method of assessing the garbage burning contribution to overall air quality. For example, the ratio $\mathrm{EF}_{\text {garbage }} / \mathrm{EF}_{\text {cook }}$ for selected particle species was: 
$\mathrm{Sb}$ (555.7), $\mathrm{Pb}$ (211.7), $\mathrm{Sn}$ (181.9), $\mathrm{Cl}^{-}$(63.7), $\mathrm{Cd}$ (33.57), As (20.9), $\mathrm{Ca}$ (5.1), and $\mathrm{Mg}$ (4.6). We note, however, that the soluble chloride in the one sample of crop residue burning smoke was actually higher than the average value for garbage burning. This could reflect the use of chlorine-containing agricultural chemicals (Sect. 3.4). In examining the ratio of the average EF for garbage burning to the average EF for crop residue burning the most elevated metals are antimony and tin (Sb 309.4, Sn 33.6). Thus, initially Sb emerges as a promising tracer for garbage burning.

Both $\mathrm{Sb}$ and $\mathrm{PM}_{2.5}$ were measured in the MCMA ambient air at $T_{0}$ and $T_{1}$ during MILAGRO (Querol et al., 2008). The mean mass ratio for $\mathrm{Sb} / \mathrm{PM}_{2.5}$ for the March 2006 campaign at these sites was 0.000315 . Our mean EF for $\mathrm{Sb}$ in $\mathrm{PM}_{2.5}$ from pure garbage burning smoke was $0.011 \pm 0.008 \mathrm{~g} / \mathrm{kg}$. Our estimate of the average $\mathrm{EFPM}_{2.5}$ for garbage burning is $10.5 \pm 8.8 \mathrm{~g} / \mathrm{kg}$, implying a $\mathrm{Sb} / \mathrm{PM}_{2.5}$ mean mass ratio of $\sim 0.0011$ for this source. Comparison of the mean mass ratios of $\mathrm{Sb} / \mathrm{PM}_{2.5}$ for pure garbage burning and ambient air implies that garbage burning could account for up to about $28 \%$ of the $\mathrm{PM}_{2.5}$ in the MCMA. However, we note that this estimate has high uncertainty and that $\mathrm{Sb}$ in the MCMA particulate could also result from other sources; especially metal production and processing (Reff et al., 2009). However, our initial upper limit suggests that garbage burning deserves more attention as a potentially significant contributor to the particle burden of the MCMA airshed. A more rigorous source attribution for garbage burning based on fine particle metal content would require a more complex multielement approach. The main uses of antimony are as a flame retardant for textiles and in lead alloys used in batteries. Antimony trioxide is a catalyst that is often used in the production of polyethylene terephthalate (PET) and that remains in the material. PET is the main material in soft drink bottles, polyester fiber for textiles, Dacron, and Mylar. The smoke particles from the dump with the highest percentage of textiles (Table 4, garbage fire 3) did have the highest mass percentage of Sb. We noted earlier that at least some of the PET materials (soft drink bottles) were being recycled rather than burned.

\subsection{Industrial biofuel use: brick and charcoal making kilns}

\subsubsection{Brick making kilns}

The particle and trace gas emissions data for brick kilns are in Tables 4 and 5, respectively. The brick kilns we sampled burned mostly biomass fuels and the identities of the emitted NMOC were similar to those from biomass burning. The brick kiln EF were much reduced, likely due to the high MCE and to scavenging by the kiln walls and/or the bricks themselves. It is hard to say how well the emissions from these kilns represent brick making kilns in general because informal industries like brick kilns often burn a combination of biofuel, garbage, painted boards, tires, used motor oil, etc. Though our kilns burned mostly biofuel they emitted a much blacker smoke than any other biomass burning we have observed (EC/OC 6.72, n=2). All the photographs of brick making kilns we took and could locate elsewhere showed very black smoke emissions. The high $\mathrm{EFCl}^{-}$, but low $\mathrm{Sb}$ and other metals for brick kiln 1 suggests that crop waste may have been a fuel component during our measurements or during past uses of the kiln. The elevated $\mathrm{Pb}$ from both kilns 1 and 2 may be due to burning painted boards from demolished buildings. Painted boards were identified as a controversial fuel used in some Mexican brick kilns in a report to the USEPA by James Anderson of Arizona State University (http://www.epa.gov/Border2012/).

The EFPM 2.5 must be quite low from our brick kilns as the sum of the species on the two kiln filters was 1.24 and $1.96 \mathrm{~g} / \mathrm{kg}$, respectively. Some of the particles being produced in the fire-box may be deposited on the bricks and kiln walls. Despite the low particle emission factors for these kilns, brick making kilns are known to cause locally severe air quality impacts in Mexico as documented by Anderson, who reported $\mathrm{PM}_{10}$ in homes and an elementary school near brick kilns well above $1000 \mu \mathrm{g} / \mathrm{m}^{3}$. Blackman et al. (2006) reported that the 330 brick making kilns in Ciudad Juarez (population 1.2 million) produced $16 \%$ of the $\mathrm{PM}$ and $43 \%$ of the $\mathrm{SO}_{2}$ in the urban airshed. A large reduction in the total emissions from brick kilns is possible at the regional-national scale by switching to more fuel efficient designs such as the vertical shaft brick kiln (http://www.vsbkindia.org/faq.htm).

To our knowledge, there are no other published data on trace gas and particle emissions for brick making kilns that use wood or cellulose-based waste products as the primary fuel. An inventory of China's CO emissions was constructed following the Transport and Chemical Evolution over the Pacific (TRACE-P) campaign of 2001 (Streets et al., 2003). Those data were recently reevaluated to include a much larger contribution from coal-fired brick kilns (Streets et al., 2006). In a modeling study of aerosol over south Asia, a lack of seasonal variability for Kathmandu was credited to the exclusion of brick kiln emissions from the model (Adhikary et al., 2007). Nepalese kilns are also fueled primarily by coal.

The impact of industrial biofuel use will likely remain difficult to assess for some time. The diverse range of microenterprise fuels (biomass, motor oil, tires, garbage, propane, coal, crop residues, etc) makes it difficult to envision a tracerbased method that would quantitatively retrieve the contribution of this sector of the economy. Survey-based methods, which likely work well for household biofuel use, may be less accurate when applied to highly competitive enterprises operating on thin margins. For example, in the report by Anderson cited above, stockpiled tires were a common sight at brick kilns. However, $100 \%$ of owners surveyed responded that they never burned tires while $12 \%$ responded that other kiln owners did. 
Table 6. Comparison of normalized emission ratios (ER, mol/mol) and emission factors $(\mathrm{EF}, \mathrm{g} / \mathrm{kg} \text { dry fuel })^{\mathrm{a}}$ for 3 charcoal kilns in central Mexico with a charcoal kiln in Zambia.

\begin{tabular}{|c|c|c|c|c|c|c|c|c|c|}
\hline & \multicolumn{5}{|c|}{ Current study ${ }^{\mathrm{b}}$} & \multirow{3}{*}{ stdev } & \multicolumn{2}{|c|}{ Zambia $^{\mathrm{c}}$} & \multirow{3}{*}{$\begin{array}{l}\text { Current/ } \\
\text { Zambia }\end{array}$} \\
\hline & \multicolumn{4}{|c|}{ ER } & avg & & avg & stdev & \\
\hline & day 2 & day 3 & day 4 & day 5 & & & & & \\
\hline MCE & 0.818 & 0.800 & 0.829 & 0.809 & 0.814 & 0.012 & 0.783 & 0.042 & 1.04 \\
\hline$\Delta \mathrm{CO} / \Delta \mathrm{CO}_{2}$ & 0.223 & 0.250 & 0.207 & 0.236 & 0.229 & 0.018 & 0.280 & 0.071 & 0.82 \\
\hline$\Delta \mathrm{CH}_{4} / \Delta \mathrm{CO}$ & 0.151 & 0.160 & 0.273 & 0.336 & 0.230 & 0.090 & 0.242 & 0.073 & 0.95 \\
\hline$\Delta \mathrm{MeOH} / \Delta \mathrm{CO}$ & 0.155 & 0.210 & 0.308 & 0.142 & 0.204 & 0.075 & 0.111 & 0.070 & 1.84 \\
\hline$\Delta \mathrm{NH}_{3} / \Delta \mathrm{CO}$ & 0.0032 & 0.0024 & 0.0032 & 0.000 & 0.002 & 0.001 & 0.006 & 0.002 & 0.38 \\
\hline$\Delta \mathrm{C}_{2} \mathrm{H}_{4} / \Delta \mathrm{CO}$ & 0.007 & 0.006 & 0.010 & 0.015 & 0.009 & 0.004 & 0.013 & 0.002 & 0.72 \\
\hline$\Delta \mathrm{C}_{2} \mathrm{H}_{2} / \Delta \mathrm{CO}$ & & 0.0005 & 0.0008 & & 0.0007 & & & & \\
\hline$\Delta \mathrm{C}_{3} \mathrm{H}_{6} / \Delta \mathrm{CO}$ & 0.006 & 0.004 & 0.010 & 0.008 & 0.007 & 0.003 & 0.010 & 0.005 & 0.68 \\
\hline$\Delta \mathrm{HAc} / \Delta \mathrm{CO}$ & 0.109 & 0.164 & 0.341 & 0.119 & 0.183 & 0.108 & 0.043 & 0.031 & 4.26 \\
\hline \multirow[t]{2}{*}{$\Delta \mathrm{HFo} / \Delta \mathrm{CO}$} & & 0.002 & 0.003 & & 0.002 & & 0.003 & 0.001 & 0.82 \\
\hline & \multicolumn{4}{|c|}{$\mathrm{EF}$} & avg & stdev & avg & & \\
\hline $\mathrm{CO}_{2}$ & 612 & 577 & 558 & 582 & 582 & 23 & 542 & & 1.07 \\
\hline $\mathrm{CO}$ & 87.0 & 91.7 & 73.3 & 87.4 & 84.9 & 8.0 & 96.8 & & 0.88 \\
\hline $\mathrm{CH}_{4}$ & 7.52 & 8.37 & 11.46 & 16.77 & 11.0 & 4.19 & 13.4 & & 0.82 \\
\hline $\mathrm{MeOH}$ & 15.4 & 22.0 & 25.8 & 14.2 & 19.4 & 5.48 & 12.3 & & 1.58 \\
\hline $\mathrm{NH}_{3}$ & 0.17 & 0.14 & 0.14 & 0.02 & 0.12 & 0.07 & 0.37 & & 0.31 \\
\hline $\mathrm{C}_{2} \mathrm{H}_{4}$ & 0.60 & 0.55 & 0.74 & 1.28 & 0.79 & 0.33 & 1.31 & & 0.60 \\
\hline $\mathrm{C}_{2} \mathrm{H}_{2}$ & & 0.04 & 0.06 & & 0.05 & & & & \\
\hline $\mathrm{C}_{3} \mathrm{H}_{6}$ & 0.73 & 0.48 & 1.08 & 1.10 & 0.85 & 0.30 & 1.50 & & 0.56 \\
\hline HAc & 20.3 & 32.1 & 53.6 & 22.3 & 32.1 & 15.2 & 8.92 & & 3.60 \\
\hline $\mathrm{HFo}$ & & 0.34 & 0.32 & & 0.33 & 0.02 & 0.45 & & 0.73 \\
\hline $\mathrm{HCHO}$ & & & & & & & 1.06 & & \\
\hline NMOC & 37.1 & 55.5 & 81.6 & 38.9 & 53.3 & 20.6 & 32.8 & & 1.62 \\
\hline
\end{tabular}

${ }^{a}$ See Sect. 2.3 for details specific to EF calculations for charcoal kilns. ${ }^{\mathrm{b}} 36$ spot measurements from 3 charcoal kilns. ${ }^{\mathrm{c}} 3 \sim 1 \mathrm{~h}$ measurements over the course of 4 days from a charcoal kiln in Zambia (Bertschi et al., 2003). $\mathrm{MeOH}$ - methanol; HAc - acetic acid; HFo - formic acid; NMOC - the sum of non-methane organic compounds measured by FTIR.

\subsubsection{Charcoal making kilns}

The particle and trace gas emissions data for the charcoal making kilns are in Tables 4 and 6, respectively. As noted by Christian et al. (2007) the chemistry of the kiln emissions changes over the course of the approximately one-week production cycle. Specifically the molar ratio of total (measurable) VOC to CO increases by about a factor of 8 over this time. Thus, it is most meaningful to compare measurements from the same point in the production cycle, which we have done in Fig. 4. The pattern of increasing total $\Delta \mathrm{VOC} / \Delta \mathrm{CO}$ for Mexico is fairly similar to the trend measured on charcoal kilns in Brazil (Christian et al., 2007) and Africa (Bertschi et al., 2003).

Table 6 also includes a simple comparison between the average of the charcoal making EF measured on days 3-5 in Mexico and the average EF for days 1-4 from a Zambian charcoal kiln (Bertschi et al., 2003). The Mexico MCE is slightly higher than the Zambian MCE, but the Mexican EF for acetic acid was 360\% higher. Andreae and Merlet (2001)

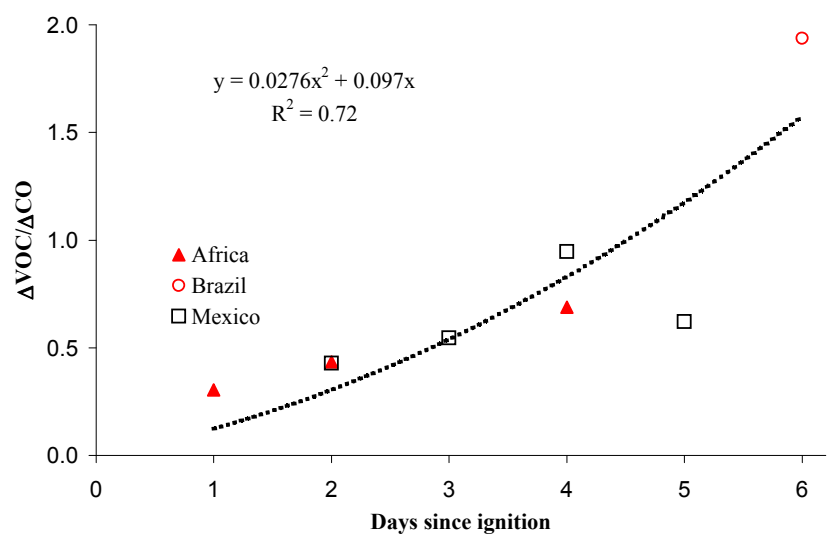

Fig. 4. The sum of $\Delta \mathrm{VOC} / \Delta \mathrm{CO}$ versus approximate kiln age for charcoal making kilns (see Sect. 3.3.2). 
recommended an EFTPM for charcoal making of $4.0 \mathrm{~g} / \mathrm{kg}$. The sums of the EF for our $\mathrm{PM}_{2.5}$ species in the two kiln filters were below that at 0.56 and $1.65 \mathrm{~g} / \mathrm{kg}$, respectively (Table 4). While a thick white smoke emanates from the vents in the kiln walls, much of the particulate matter produced inside probably remains embedded in the dirt walls while most of the gases are vented.

\subsection{Crop residue burning}

Our emissions data for crop residue fires are in Tables 4 and 5 in the columns labeled "stubble burns". Yokelson et al. (2009) reported airborne EF measurements for six crop residue fires in the Yucatan peninsula. Since airborne platforms tend to sample smoke with a higher flaming/smoldering ratio than ground-based platforms, we expect that the airborne samples will have a higher MCE and lower EF for smoldering compounds and $\mathrm{PM}_{2.5}$. This pattern is observed. The airborne average MCE was 0.934 , while the ground-based average MCE was 0.896 . The airborne average $\mathrm{EF}$ for smoldering compounds (excluding formic acid) and $\mathrm{PM}_{2.5}$ were $65 \pm 12 \%$ of the average EF measured from the ground. The formic acid average EF was higher for the fires sampled from the air, possibly due to fuel differences. The type of crop residue burning could not be identified from the air. In the future, after analyzing additional airborne samples of crop residue fires from our flights in Mexico, we plan to recommend $\mathrm{EF}$ weighted by the relative fuel consumption for flaming and smoldering combustion.

Table 4 includes a very low EC/OC ratio for the one filter sample of stubble burning smoke. $\mathrm{K}$ and $\mathrm{Na}$ were very high on this filter and are known to catalytically lower the combustion temperature of black carbon during thermal evolution carbon analysis methods (Martins et al., 1998; Novakov and Corrigan, 1995). Straw seems to have a characteristic high levoglucosan/mannosan ratio (e.g. 40 for rice straw). The ratio (47) in our stubble burning smoke is in good agreement with literature data (Engling et al., 2009 and references therein). The stubble burn filter had a high chloride content and a $\mathrm{Cl}^{-} / \mathrm{K}^{+}$ratio (2.6) that agree well with measurements of aerosol from burning rice straw (Engling et al., 2009). The high particle chloride for crop residue burning may be linked to the use of agricultural chemicals. Typical examples of these products include the herbicide 2,4-D dimethylamine salt $(26.6 \% \mathrm{Cl}$ by mass), the fungicide chlorthalonil (1,3-dicyanotetrachlorobenzene, $53 \% \mathrm{Cl})$, and the pesticide Lindane (or Kwell, hexachlorocyclohexane, $73 \% \mathrm{Cl}$ ). Two fires were sampled by the NCAR C-130 during MILAGRO in fuels that could not be identified from the air (fires \#1 and \#3 sampled on 23 March 2006, Yokelson et al., 2009). The particles emitted by these fires were high in both $\mathrm{Cl}^{-}$and $\mathrm{NO}_{3}^{-}$so they could have been crop residue fires. Fire plays a role in redistributing agricultural chemicals from their original point of application and they then build up in fire-free areas such as the Arctic (Becker et al., 2009).

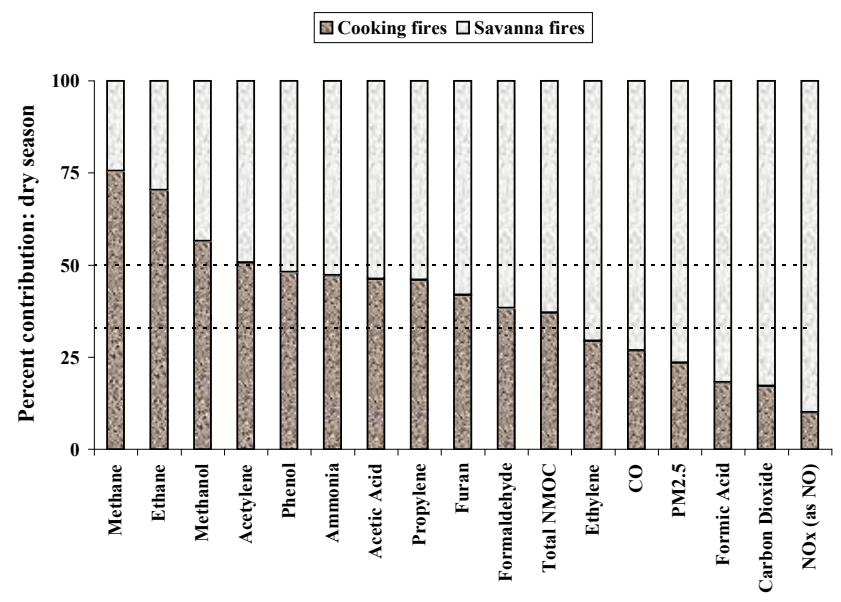

Fig. 5. Percentage of total dry season pyrogenic emissions due to cooking fires or savanna fires in a mostly rural developing country (see Sect. 4.1). If the dry season percentage attributed to cooking fires for a species extends above the $33 \%$ line indicated, the total annual emissions of that species will be greater from cooking fires.

\section{Implications}

In this section we discuss the impact of the sources sampled in this work at various scales. For cooking fires we start with national scale assessments for two different scenarios: a mostly rural developing country (Zambia) and a mostly urban developing country (Mexico).

\subsection{Cooking fires compared to open burning in a mostly rural developing country}

Zambia has a total population of 10 million, of which $60 \%$ is rural. As much as one-third of the area of the country can burn in open fires in a single year which, combined with the small population, suggests that cooking fires would be much less important than open burning. However, standard estimation methods reveal otherwise. In Fig. 5 we compare the dry season emissions from open fires and biofuel use based on the following assumptions: $18.6 \mathrm{Tg} / \mathrm{y}$ biomass burned in open fires, $6.4 \mathrm{Tg} / \mathrm{y}$ biomass burned in wood cooking fires, and $0.75 \mathrm{Tg} / \mathrm{y}$ charcoal use (Bertschi et al., 2003). EF for these combustion types, specific to Zambia when available, are from several sources (Andreae and Merlet, 2001; Bertschi et al., 2003; Christian et al., 2003; Sinha et al., 2004; Yokelson et al., 2008). We divide the annual biofuel emissions by two to estimate the dry season cooking fire emissions, and all the annual open burning emissions are assumed to be generated in the dry season. From Fig. 5 it is apparent that the dry season cooking fire emissions equal or exceed the dry season open burning emissions for four of the 17 species measured from both sources. For 11 of the 17 species, the dry season cooking fire emissions are at least $33 \%$ - or 1 part in 3 - of the total dry season pyrogenic 
Table 7. Comparison of cooking fire and urban emissions for Mexico.

\begin{tabular}{lcccccc}
\hline & $\mathrm{PM}_{2.5}$ & $\mathrm{NMOC}$ & $\mathrm{CO}$ & $\mathrm{NO}_{\mathrm{x}}$ & $\mathrm{CH}_{4}$ & $\mathrm{NH}_{3}$ \\
\hline Biofuel emission factor (g/kg) & $6.73^{\mathrm{a}}$ & $54^{\mathrm{b}}$ & $58.4^{\mathrm{a}}$ & $2.04^{\mathrm{c}}$ & $3.35^{\mathrm{a}}$ & $0.44^{\mathrm{a}}$ \\
Annual national biofuel emissions (Tg) & 0.46 & 3.67 & 3.97 & 0.14 & 0.23 & 0.03 \\
Annual MCMA emissions (Tg) & 0.0066 & 0.53 & 1.79 & 0.18 & 0.24 & 0.018 \\
Ratio: national biofuels/MCMA & 69.11 & 6.90 & 2.22 & 0.77 & 0.97 & 1.71 \\
National urban emissions (Tg) & 0.025 & 1.98 & 6.68 & 0.67 & 0.88 & 0.065 \\
National biofuel/National urban & 18.53 & 1.85 & 0.59 & 0.21 & 0.26 & 0.46 \\
\hline
\end{tabular}

${ }^{a}$ This work. ${ }^{b}$ Yokelson et al. (2008). ${ }^{c}$ Bertschi et al. (2003).

emissions. By doubling the emissions of those 11 species to account for year round use, they now constitute at least $50 \%$ - or 2 parts in 4 - of the total annual emissions.

\subsection{Cooking fires compared to urban emissions in a mostly urban developing country}

Mexico's total population of 100 million is $75 \%$ urban. Mexico City (population 20 million, $\sim$ double the entire country of Zambia) is the second largest Megacity on earth and an acknowledged major source of pollutants. Mexico has experienced strong rural to urban migration and is considerably more developed than Zambia. We roughly estimate annual biofuel use in Mexico using three tables in Yevich and Logan (2003). From their Table 12 Mexico accounts for $13 \%$ of biofuel use in Latin America on an energy basis. From their Table 13 the annual biofuel consumption for Latin America is $358 \mathrm{Tg}$. And from their Table 16 they estimate a $20 \%$ increase in biofuel use every 10 years. We applied this increase to the values from the other tables, which were based on 1988 data. In this way we arrive at $68 \mathrm{Tg} / \mathrm{y}$ of biofuel consumption for Mexico, which is mainly cooking fires. We are unsure to what extent this estimate may or may not include potentially substantial industrial biofuel use. We obtained speciated annual emissions for the Mexico City Metropolitan Area (MCMA) from the 2004 MCMA emissions inventory (http://www.sma.df.gob.mx/sma/index.php? opcion=26\{\\&\}id=392). We multiply the MCMA emissions by $75 / 20$ to roughly estimate total annual urban emissions for Mexico. Since both urban and cooking emissions are year round we do not separately calculate dry season emissions because the ratio between the sources would not change. Table 7 summarizes this simple comparison and suggests that $\sim 2$ times more NMOC are generated from cooking fires than from urban areas. In addition, $\mathrm{PM}_{2.5}$ is estimated to be almost 20 times greater from cooking fires than from urban areas on a national basis. Even if we allowed for a higher degree of secondary aerosol formation in fossil fuel emissions, which may not be the case, the cooking fires clearly dominate. These estimates are highly uncertain, but indicate that a switch to cleaner burning, more fuel-efficient stoves (Sect. 3.1) could provide a significant reduction of emissions on the national scale.
Though biofuel use is thought to occur mainly in rural areas, it is possible that a significant amount of biofuel use also occurs in urban areas. Marley et al. (2009) reported that 70\% of the carbon in the ambient MCMA aerosol was modern and ascribed this to open biomass burning and garbage burning. Garbage burning consumes some modern carbon, but also a large amount of plastics derived from fossil fuels. Some studies suggest a higher proportion of food waste for Mexican dumps than we estimated (Buenrostro and Bocco, 2003; Ojeda-Benitez et al., 2003; De la Rosa et al., 2009), which, if true, would not affect our $\% \mathrm{C}$, but could increase the fraction of modern carbon. However, indications are that much of the food waste may decompose before burning (BernachePérez et al., 2001). If open burning was the dominant particle source in the MCMA and ventilation rates were similar year round, the $\mathrm{PM}_{10}$ levels should peak in March-May when nearly all the open biomass burning occurs. Instead the $\mathrm{PM}_{10}$ data show at best a weak increase in $\mathrm{PM}_{10}$ during these months (Fig. 6) indicating that a different, year round source of modern carbon could be "embedded" in the urban area. Possibilities include cooking fires and industrial biofuel use in addition to garbage burning.

\subsection{Garbage burning impacts on the local-global atmosphere}

We start this section by noting that the prevalence of open burning of garbage may be greater than commonly supposed even in developed countries. As noted earlier, it has been estimated that $12-40 \%$ of rural households in the US burn garbage in their backyards (USEPA, 2006). In the US, dump and landfill fires are reported at a rate of 8400 fires per year (TriData Corp., 2002). UK landfill operators surveyed by Bates (2004) estimated that, at any one time, deep seated fires are occurring at about 80 percent of landfills.

If we assume that $1000 \mathrm{Tg}$ of garbage with a $\mathrm{Cl}$ content of $0.9 \%$ are burned each year globally (see introduction and Sect. 3.2), this could volatilize as much as $9 \mathrm{Tg} / \mathrm{yr}$ of $\mathrm{Cl}$. This suggests a potential global source of 6-9 Tg/yr of $\mathrm{HCl}$. By comparison, the Reactive Chlorine Emissions Inventory (Keene et al., 1999) estimated that $\mathrm{HCl}$ from garbage burning was $2 \mathrm{Tg} / \mathrm{yr}$ and that sea salt dechlorination was the main 


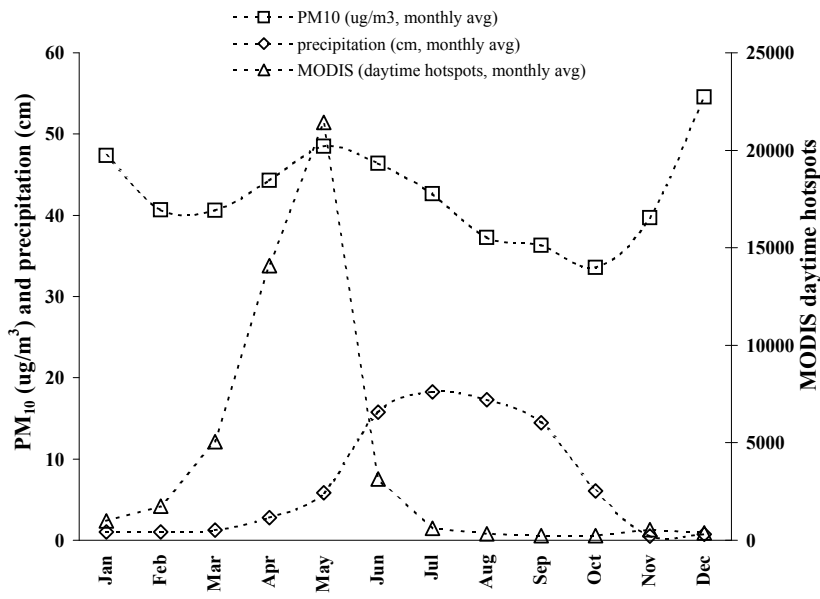

Fig. 6. Time series of monthly average $\mathrm{PM}_{10}$ (Pedregal RAMA station 2003-2008 average, www.sma.df.gob.mx/simat/cambia_base. htm); MODIS daytime hotspots for Mexico (2003-2008 average, www.conabio.gob.mx); and monthly average precipitation for MCMA (see Sect. 4.2).

global source at $7.6 \mathrm{Tg} / \mathrm{yr}$. Recent $\mathrm{HCl}$ profiles in the marine boundary layer (Kim et al., 2008) may indicate that the sea salt dechlorination $\mathrm{HCl}$ source was over estimated. Our measurements indicate that the garbage burning $\mathrm{HCl}$ source may have been underestimated. In general, Keene et al. (1999) found that additional $\mathrm{HCl}$ sources totaling to $42 \mathrm{Tg} / \mathrm{yr}$ were needed to balance the $\mathrm{HCl}$ budget. With the above in mind, we propose that garbage burning may be a considerably more important tropospheric source of $\mathrm{HCl}$ than previously assumed. We also note that many of the other main $\mathrm{HCl}$ sources, such as sea salt and volcanoes, can often be associated with a humid environment and rapid removal of $\mathrm{HCl}$ (Tabazadeh and Turco, 1993). In dry environments, such as central Mexico where we measured water mixing ratios as low as $890 \mathrm{ppm}$, a larger fraction of freshly emitted $\mathrm{HCl}$ might react with $\mathrm{OH}$ to release $\mathrm{Cl}$ atoms. The latter would then react with NMOC. In any case, the $\mathrm{HCl}$ from garbage burning in dryer areas could have a longer lifetime and higher relative importance than the same amount of $\mathrm{HCl}$ emitted in wetter areas.

We examined data obtained by other MILAGRO investigators for possible evidence of garbage burning. A particlesinto-liquid-sampler (PILS) deployed by Georgia Tech at the MILAGRO T1 ground station north of Mexico City during March 2006 observed chloride (up to $6 \mu \mathrm{g} / \mathrm{m}^{3}$ ) for most of the month, with an average of $0.5 \mu \mathrm{g} / \mathrm{m}^{3}$ compared to $33 \mu \mathrm{g} / \mathrm{m}^{3}$ total $\mathrm{PM}_{2.5}$ (Greg Huey, personal communication, 2009). This translates to a mass ratio of 0.015 . The average mass ratio of $\mathrm{Cl}^{-}$to the sum of particle species in our nascent smoke from garbage burning (Table 4) was $0.047 \pm 0.011$. Thus, the PILS data suggests an approximate upper limit for the contribution of garbage burning to the $\mathrm{PM}_{2.5}$ in the MC airshed that is similar to that from the $\mathrm{Sb}$ data $(\sim 1 / 3)$. As with $\mathrm{Sb}$ there are other $\mathrm{Cl}$ sources that could lower the garbage burning contribution such as agricultural fires, brick making kilns (Table 4) and volcanoes (e.g. Burton et al., 2007). We note that 3 of the 4 landfills we sampled are within $\sim 35 \mathrm{~km}$ to the west, north, and east of the T1 site (Table 1). We also note that $\mathrm{EFCl}^{-}$for brick kiln 1 was high and that this kiln is only $\sim 20 \mathrm{~km}$ west of T1. In addition, brick kiln 1 was one of many brick kilns in the region. Reff et al. (2009) list a number of source profiles with high $\mathrm{Cl}^{-} / \mathrm{PM}_{2.5}$ ratios including solid waste combustion, agricultural burning, various types of metallurgy, and other (less common?) industrial processes. Moffet et al. (2008) assigned much of the particulate $\mathrm{Cl}^{-}$in the MCMA to waste incineration based partly on a lack of correlation between particle $\mathrm{Cl}^{-}$and $\mathrm{SO}_{2}$, which is often produced by metallurgy and partly on a similarity of the ambient profile to the profile for waste incineration, which is known to occur in northern Mexico City.

We also looked for evidence of chlorine atom chemistry in the hydrocarbon ratios measured by whole air sampling. A plot of i-butane versus n-butane for 62 canister samples collected from both airborne and ground based sampling locations in and around MCMA gave an average i-butane/nbutane ratio of $0.33\left(r^{2}=1.00\right.$, Don Blake, Barbara Barlett, personal communication, 2009). This is consistent with minimal chlorine atom oxidation of alkanes in the air sampled (Kim et al., 2008).

We make two other general points about garbage burning. More work is needed to measure other chlorinated emissions from burning refuse, including $\mathrm{CH}_{3} \mathrm{Cl}$, which is also a proposed biomass burning tracer (Lobert et al., 1991). Secondly, PVC (the primary source of $\mathrm{HCl}$ in garbage burning emissions) is also the most important predictor of dioxin emissions from the open burning of domestic waste (Neurath, 2004), so removing PVC from the waste before burning should have multiple benefits.

\section{Conclusions}

This work measured initial emission ratios and emission factors for trace gas and particle species from five prominent, little-studied combustion sources: wood cooking fires, garbage burning, brick and charcoal making kilns, and crop residue burning. For Zambia, a mostly rural developing country, annual emissions from cooking fires likely exceed those from savanna fires for $\sim 11$ of the 17 most abundant species measured from both sources. For Mexico, a mostly urban developing country, NMOC from cooking fires are estimated to be substantially higher than from urban fossil fuel sources. Furthermore, cooking fires emit far more primary $\mathrm{PM}_{2.5}$ than urban fossil fuel sources on a national scale in Mexico. Therefore, the use of improved stoves that reduce both total fuel consumption per cooking task and the pollutant emissions per unit fuel consumption could provide large reductions in pollutant emissions throughout the developing 
world. Cooking fires produce far less HCN per unit mass of fuel than landscape-scale open biomass burning. Thus, the use of HCN ER or EF appropriate for open burning to estimate regional biomass burning could cause a substantial underestimate of total biomass burning in areas where cooking fires are common (most of the developing world). Acetonitrile emissions from cooking fires are also likely to be much lower than for other biomass burning types. In addition, levoglucosan, $\mathrm{K}$, and $\mathrm{CH}_{3} \mathrm{Cl}$ are likely not suitable as biomass burning tracers in areas where garbage burning is common. Since cooking fires are also not detected from space a need exists to identify a chemical tracer for this source, which is currently quantified only by user surveys.

Garbage burning is a globally significant source of particles and trace gases and may be a major global source of $\mathrm{HCl}$. The emissions of particle EC, OC, levoglucosan, and $\mathrm{K}$ were similar for garbage burning and cooking fires. Of the three anhydrosugars we measured, galactosan was the one most closely associated with biomass burning. Thus, it shows some promise for distinguishing between garbage burning and general biomass burning. Antimony $(\mathrm{Sb})$ is a potential tracer for garbage burning. Comparison of both the $\mathrm{Sb}$ and the $\mathrm{Cl}^{-}$mass concentrations in the ambient $\mathrm{PM}_{2.5}$ sampled at points in the MCMA airshed with the mass concentration of these species in $\mathrm{PM}_{2.5}$ in fresh garbage burning plumes tentatively suggests that landfill fires may produce an upper limit of about one-third of the $\mathrm{PM}_{2.5}$ in some areas of the MCMA.

Wood-fueled brick making kilns emitted a suite of trace gases similar to those from biomass burning, but with much lower emission factors. Smoke from these kilns had a very high EC/OC ratio. Charcoal making kilns in Mexico, Brazil, and Africa exhibited a consistent pattern of increasing VOC/CO emission ratios over their approximately one week lifespan. The Mexican charcoal kilns produced higher acetic acid to $\mathrm{CO}$ ratios than an African kiln. The $\mathrm{PM}_{2.5}$ emission factor for both kiln types was evidently low relative to other biomass burning types, possibly as a result of particlescavenging on the kiln charge and walls. The fuels for brick making kilns vary substantially in ways that will likely remain difficult to quantify and limit the accuracy of regional air quality assessments and global emissions inventories. A single filter sample of smoke from a crop residue fire had very high levels of chloride that probably resulted from the use of agricultural chemicals. More research is needed to identify the nature and fate of the combustion products of agricultural chemicals.
Acknowledgements. We gratefully acknowledge the kind assistance of the following people: O. Masera, S. Blanco, E. Alvarado, H. Wöhrnschimmel, E. I. L. Díaz, F. A. Garcìa, R. GonzálezAbraham, J. M. M. Fuentes, C. Armendariz, J. Cruz, and V. Berrueta. This research was supported mostly by NSF grant ATM-0513055. Yokelson was also supported by the Dept of Defense Strategic Environmental Research and Development Program (SERDP); the Rocky Mountain Research Station, Forest Service, US Department of Agriculture (agreement 07-JV-11221649-060); and the Pacific Southwest Research Station, Forest Service, US Department of Agriculture (agreement 08-JV-11272166-039).

Edited by: J. Gaffney

\section{References}

Adhikary, B., Carmichael, G. R., Tang, Y., Leung, L. R., Qian, Y., Schauer, J. J., Stone, E. A., Ramanathan, V., and Ramana, M. V.: Characterization of the seasonal cycle of south Asian aerosols: A regional-scale modeling analysis, J. Geophys. Res., 112, D22S22, doi:10.1029/2006JD008143, 2007.

Aiken, A. C., DeCarlo, P. F., Kroll, J. H., et al.: $\mathrm{O} / \mathrm{C}$ and OM/OC Ratios of Primary, Secondary, and Ambient Organic Aerosols with High-Resolution Time-of-Flight Aerosol Mass Spectrometry, Environ. Sci. Technol., 42(12), 4478-4485, doi:10.1021/es703009q, 2008.

Andreae, M. O. and Merlet, P.: Emission of trace gases and aerosols from biomass burning, Global Biogeochem. Cy., 15(4), 955-966, doi:10.1029/2000GB001382, 2001.

Bates, M.: Managing landfill site fires in Northamptonshire, SITA - Sustainable Wastes Management Centre, Waste Management Library, University College Northampton, Northamptonshire, UK, 39 pp., available at: http://wmlibrary.northampton.ac.uk/ catalogue.html(last access: 16 January 2010), 2004.

Becker, S., Halsall, C. J., Tych, W., Kallenborn, R., Schlabach, M., and Manø, S.: Changing sources and environmental factors reduce the rates of decline of organochlorine pesticides in the Arctic Atmosphere, Atmos. Chem. Phys. Discuss., 9, 515-540, 2009 ,

http://www.atmos-chem-phys-discuss.net/9/515/2009/.

Bertschi, I. T., Yokelson, R. J., Ward, D. E., Christian, T. J., and Hao, W. M.: Trace gas emissions from the production and use of domestic biofuels in Zambia measured by open-path Fourier transform infrared spectroscopy, J. Geophys. Res., 108(D13), 8469, doi:1029/2002/D002158, 2003.

Birch, M. E. and Cary, R. A.: Elemental carbon-based method for monitoring occupational exposures to particulate diesel exhaust, Aerosol Sci. Tech. 25(3), 221-241, 1996.

Blackman, A. and Bannister, G. J.: Pollution Control in the Informal Sector: The Ciudad Juárez Brickmakers' Project, Resources for the Future, Washington, DC, 26 pp., 1998.

Blackman, A., Shih, J.-S., Evans, D., Batz, M., Newbold, S., and Cook, J.: The benefits and costs of informal sector pollution control: Mexican brick kilns, Environment and Development Economics, 11, 603-627, doi:10.1017/S1355770X06003159, 2006.

Bernache-Pérez, G., Sánchez-Colon, S., Garmendia, A. M., DávilaVillarreal, A., and Sánchez-Salazar, M. E.: Solid waste characterization study in the Guadalajara metropolitan zone, Mexico, Waste Manage. Res., 19, 169-176, 2001. 
Bond, T. C., Streets, D. G., Yarber, K. F., Nelson, S. M., Woo, J.H., and Klimont, Z.: A technology-based global inventory of black and organic carbon emissions from combustion, J. Geophys. Res., 109, D14203, doi:10.1029/2003JD003697, 2004.

Brauer, M., Bartlett, K., Regalado-Pineda, J., and Perez-Padilla, R.: Assessment of particulate concentrations from domestic biomass combustion in rural Mexico, Environ. Sci. Technol., 30, 104 109, 1996.

Brocard, D., Lacaux, C., Lacaux, J. P., Kouadio, G., and Yoboué, V.: Emissions from the combustion of biofuels in western Africa, in: Biomass Burning and Global Change, edited by: Levine, J. S., MIT Press, Cambridge, MA, 1, 350-360, 1996.

Buenrostro, O. and Bocco, G.: Solid waste management in municipalities in Mexico: goals and perspectives, Resources, Conservation and Recycling, 39, 251-263, 2003.

Burton, M., Allard, P., Muré, F., and Spina, A. L.: Magmatic gas composition reveals the source depth of slug-driven Strombolian explosive activity, Science, 317, 227-230, 2007.

Cançado, J. E. D., Saldiva, P. H. N., Pereira, L. A. A., Lara, L. B. L. S., Artaxo, P., Martinelli, L. A., Arbex, M. A., Zanobetti, A., and Braga, A. L. F.: The Impact of Sugar Cane-Burning Emissions on the Respiratory System of Children and the Elderly, Environ. Health Perspect., 114(5), 725-729, 2006.

Christian, T. J., Kleiss, B., Yokelson, R. J., Holzinger, R., Crutzen, P. J., Hao, W. M., Saharjo, B. H., and Ward, D. E.: Comprehensive laboratory measurements of biomass-burning emissions: 1. Emissions from Indonesian, African, and other fuels, J. Geophys. Res., 108(D23), 4719, doi:10.1029/2003JD003704, 2003.

Christian, T. J., Yokelson, R. J., Carvalho Jr., J. A., Griffith, D. W. T., Alvarado, E. C., Santos, J. C., Neto, T. G. S., Veras, C. A. G., and Hao, W. M.: The tropical forest and fire emissions experiment: Trace gases emitted by smoldering logs and dung from deforestation and pasture fires in Brazil, J. Geophys. Res., 112, D18308, doi:10.1029/2006JD008147, 2007.

Costner, P.: Estimating Releases and Prioritizing Sources in the Context of the Stockholm Convention: Dioxin Emission Factors for Forest Fires, Grassland and Moor Fires, Open Burning of Agricultural Residues, Open Burning of Domestic Waste, Landfill and Dump Fires, The International POPs Elimination Project, Mexico, 40 pp., 2005.

Costner, P.: Update of Dioxin Emission Factors for Forest Fires, Grassland and Moor Fires, Open Burning of Agricultural Residues, Open Burning of Domestic Waste, Landfills and Dump Fires, International POPs Elimination Network, Mexico, 13 pp., 2006

de Gouw, J. A., Warneke, C., Scheeren, H. A., et al.: Overview of the trace gas measurements on board the Citation aircraft during the intensive field phase of INDOEX, J. Geophys. Res., 106(D22), 28453-28467, 2001.

De la Rosa, D. A., Flores, S., Encarnación, G., and Solórzano, G.: Solid waste characterization study at final disposal sites of three municipalities in the State of Mexico, Mexico. Waste Manage., in press, 2010.

Dherani, M., Pope, D., Mascarenhas, M., Smith, K. R., Weber, M., and Bruce, N.: Indoor air pollution from unprocessed solid fuel use and pneumonia risk in children aged under five years: a systematic review and meta-analysis, Bull. World Health Org., 86(5), 390-398, 2008.

Emmons, L. K., Deeter, M. N., Gille, J. C., et al.: Validation of measurements of pollution in the troposphere (MOPITT) $\mathrm{CO}$ retrievals with aircraft in situ profiles, J. Geophys. Res., 109, D03309, doi:10.1029/2003JD004101, 2004.

Engling, G., Carrico, C. M., Kreidenweis, S. M., Collett Jr., J. L., Day, D. E., Malm, W. C., Lincoln, E., Hao, W. M., Iinuma, Y., and Herrmann, H.: Determination of levoglucosan in biomass combustion aerosol by high-performance anion-exchange chromatography with pulsed amperometric detection, Atmos. Environ. 40, S299-S311, 2006.

Engling, G., Lee, J. J., Tsai, Y.-W., Lung, S.-C. C., Chou, C. C.-K., Chan, C. Y.: Size-resolved anhydrosugar composition in smoke aerosol from controlled field burning of rice straw, Aerosol Sci. Tech., 43, 662-672, 2009.

Feldstein, M., Duckworth, S., Wohlers, H. C., and Linsky, B.: The contribution of the open burning of land clearing debris to air pollution, Japca. J. Air Waste Ma., 13, 542-545, 1963.

Fernandes, S. D., Trautmann, N. M., Streets, D. G., Roden, C. A., and Bond, T. C.: Global biofuel use, 1850-2000, Global Biogeochem. Cy., 21, GB2019, doi:10.1029/2006GB002836, 2007.

Forster, P., Ramaswamy, V., Artaxo, P., et al.: Changes in Atmospheric Constituents and in Radiative Forcing, in Climate Change 2007: The Physical Science Basis, contribution of Working Group I to the Fourth Assessment Report of the Intergovernmental Panel on Climate Change, edited by: Solomon, S. D., Qin, M., Manning, Z., Chen, M., Marquis, K. B., Averyt, M. T., and Miller, H. L., Cambridge University Press, Cambridge, United Kingdom and New York, NY, USA, 129-134, 2007.

Gerstle, R. W. and Kemnitz, D. A.: Atmospheric Emissions From Open Burning, Japca. J. Air Waste Ma., 17, 324-327, 1967.

Griffith, D. W. T.: FT-IR measurements of atmospheric trace gases and their fluxes, in: Handbook of Vibrational Spectroscopy, edited by: Chalmers, J. M. and Griffiths, P. R., John Wiley \& Sons Ltd, West Sussex, UK, 4, 2823-2841, 2002.

Hsu, S.-C., Liu, S. C., Huang, Y.-T., Lung, S.-C. C., Tsai, F., Tu, J.Y., and Kao, S.-J.: A criterion for identifying Asian dust events based on Al concentration data collected from northern Taiwan between 2002 and early 2007, J. Geophys. Res., 113, D18306, doi:10.1029/2007JD009574, 2008.

Hsu, S.-C., Wong, G. T. F., Gong, G.-C., et al.: Sources, solubility, and dry deposition of aerosol trace elements over the East China Sea, Mar. Chem., doi:10.1016/j.marchem.2008.10.003, in press, 2010.

Iinuma, Y., Engling, G., Puxbaum, H., and Herrmann, H.: A highly resolved anion exchange chromatographic method for determination of saccharidic tracers for biomass combustion and primary bio-particles in atmospheric aerosol, Atmos. Environ., 43, 13671371, 2009.

IPCC, 2006: 2006 IPCC Guidelines for National Greenhouse Gas Inventories, prepared by the National Greenhouse Gas Inventories Programme, edited by: Eggleston, H. S., Buendia, L., Miwa, K., Ngara, T., and Tanabe, K., IGES, Japan, 2006.

Johnson, M., Edwards, R., Frenk, C. A., and Masera, O.: Infield greenhouse gas emissions from cookstoves in rural Mexican households, Atmos. Environ. 42, 1206-1222, 2008.

Keene, W. C., Aslam, M., Khalil, K., et al.: Composite global emissions of reactive chlorine from anthropogenic and natural sources: Reactive Chlorine Emissions Inventory, J. Geophys. Res., 104(D7), 8429-8440, 1999.

Kim, S., Huey, L. G., Stickel, R. E., Pierce, R. B., Chen, G., Avery, 
M. A., Dibb, J. E., Diskin, G. S., Sachse, G. W., McNaughton, C. S., Clarke, A. D., Anderson, B. E., and Blake, D. R.: Airborne measurements of $\mathrm{HCl}$ from the marine boundary layer to the lower stratosphere over the North Pacific Ocean during INTEXB, Atmos. Chem. Phys. Discuss., 8, 3563-3595, 2008,

http://www.atmos-chem-phys-discuss.net/8/3563/2008/.

Lemieux, P. M., Lutes, C. C., Abbott, J. A., and Aldous, K. M.: Emissions of polychlorinated dibenzo-p-dioxins and polychlorinated dibenzofurans from the open burning of household waste in barrels, Environ. Sci. Technol. 34, 377-384, 2000.

Lobert, J. M., Keene, W. C., Logan, J. A., and Yevich, R.: Global chlorine emissions from biomass burning: Reactive Chlorine Emissions Inventory, J. Geophys. Res. 104, 8373-8390, 1999.

Lobert, J. M., Scharffe, D. H., Hao, W. M., Kuhlbusch, T. A., Seuwen, R., Warneck, P., and Crutzen, P. J.: Experimental evaluation of biomass burning emissions: Nitrogen and carbon containing compounds, in: Global Biomass Burning: Atmospheric, Climatic, and Biospheric Implications, edited by: Levine J. S., MIT Press, Cambridge, 289-304, 1991.

Marley, N. A., Gaffney, J. S., Tackett, M., Sturchio, N. C., Heraty, L., Martinez, N., Hardy, K. D., Marchany-Rivera, A., Guilderson, T., MacMillan, A., and Steelman, K.: The impact of biogenic carbon sources on aerosol absorption in Mexico City, Atmos. Chem. Phys., 9, 1537-1549, 2009,

http://www.atmos-chem-phys.net/9/1537/2009/.

Martins, J. V., Artaxo, P., Liousse, C., Reid, J. S., Hobbs, P. V., and Kaufman, Y. J.: Effects of black carbon content, particle size, and mixing on light absorption by aerosols from biomass burning in Brazil, J. Geophys. Res., 103(D4), 32041-32050, 1998.

Masera, O. R., Díaz, R., and Berrueta, V. M.: From cookstoves to cooking systems: the integrated program on sustainable household energy use in Mexico, Energ. Sustain. Dev. 9(1), 25-36, 2005.

McCulloch, A., Aucott, M. L., Benkovitz, C. M., Graede, T. E., Kleiman, G., Midgley, P. M., and Li, Y. F.: Global emissions of hydrogen chloride and chloromethane from coal combustion, incineration and industrial activities: Reactive Chlorine Emissions Inventory, J. Geophys. Res., 104(D7), 8391-8403, 1999.

Mersiowsky, I., Stegman, R., and Ejlertsson, J.: Long-term behaviour of poly (vinyl chloride) products under soil-buried and landfill conditions, Plast. Rubber Compos., 28, 7, 321-326, 1999.

Moffet, R. C., Desyaterik, Y., Hopkins, R. J., Tivanski, A. V., Gilles, M. K., Wang, Y., Shutthanandan, V., Molina, L. T., Abraham, R. G., Johnson, K. S., Mugica, V., Molina, M. J., Laskin, A., and Prather, K.: Characterization of aerosols containing $\mathrm{Zn}, \mathrm{Pb}$, and $\mathrm{Cl}$ from an industrial region of Mexico City, Environ. Sci. Technol., 42, 7091-7097, 2008.

Molina, L. T., Kolb, C. E., de Foy, B., Lamb, B. K., Brune, W. H., Jimenez, J. L., Ramos-Villegas, R., Sarmiento, J., ParamoFigueroa, V. H., Cardenas, B., Gutierrez-Avedoy, V., and Molina, M. J.: Air quality in North America's most populous city overview of the MCMA-2003 campaign, Atmos. Chem. Phys., 7, 2447-2473, 2007, http://www.atmos-chem-phys.net/7/2447/2007/.

Molina, L. T., Madronich, S., Gaffney, J. S., and Singh, H. B.: Overview of MILAGRO/INTEX-B campaign, IGAC Newsletter, 38, 2-15, 2008.

Neurath, C.: PVC's role in dioxin emissions from open burn- ing: New analysis of US EPA data, Organohalogen Cmpds., 66, 1146-1152, 2004.

Novakov, T. and Corrigan, C. E.: Thermal Characterization of Biomass Smoke Particles, Mikrochim. Acta, 119, 157-166, 1995.

Ojeda-Benitez, S., de Vega, C. A., and Ramírez-Barreto, M. E.: Characterization and quantification of household solid wastes in a Mexican City, Resources, Conservation and Recycling, 39, 211-222, 2003.

Querol, X., Pey, J., Minguillón, M. C., Pérez, N., Alastuey, A., Viana, M., Moreno, T., Bernabé, R. M., Blanco, S., Cárdenas, B., Vega, E., Sosa, G., Escalona, S., Ruiz, H., and Artíñano, B.: PM speciation and sources in Mexico during the MILAGRO-2006 Campaign, Atmos. Chem. Phys., 8, 111-128, 2008,

http://www.atmos-chem-phys.net/8/111/2008/.

Raga, G. B., Baumgardner, D., Castro, T., Martinez-Arroyo, A., and Navarro-Gonzalez, R.: Mexico City air quality: a qualitative review of gas and aerosol measurements (1960-2000), Atmos. Environ., 35, 4041-4058, 2001.

Ranis, G. and Stewart, F.: V-goods and the role of the urban informal sector in development, Yale University Economic Growth Center Discussion Paper No. 724, New Haven, 1994.

Reff, A., Bhave, P. V., Simon, H., Pace, T. G., Pouliot, G. A., Mobley, D., and Houyoux, M.: Emissions inventory of $\mathrm{PM}_{2.5}$ trace elements across the United States, Environ. Sci. Technol., 43, 5790-5796, 2009.

Roden, C. A., Bond, T. C., Conway, S., Pinel, A. B. O., MacCarty, N., and Still, D.: Laboratory and field investigations of particulate and carbon monoxide emissions from traditional and improved cookstoves, Environ. Sci. Technol., 40(21), 6750-6757, doi:10.1021/es052080i, 2006.

Roden, C. A., Bond, T. C., Conway, S., Pinel, A. B. O., MacCarty, N., and Still, D.: Laboratory and field investigations of particulate and carbon monoxide emissions from traditional and improved cookstoves, Atmos. Environ., 43, 1170-1181, 2009.

Schneider, F. and Enste, D. H.: Shadow economies: size, causes, and consequences, J. Econ. Lit., 38, 77-114, 2000.

Simoneit, B. R. T., Kobayashi, M., Mochida, M., Kawamura, K., and Huebert, B. J.: Aerosol particles collected on aircraft flights over the northwestern Pacific region during the ACE-Asia campaign: Composition and major sources of the organic compounds, J. Geophys. Res., 109, D19S09, doi:10.1029/2004JD004565, 2004a.

Simoneit, B. R. T., Kobayashi, M., Mochida, M., Kawamura, K., Lee, M., Lim, H.-J., Turpin, B. J., and Komazaki, Y.: Composition and major sources of organic compounds of aerosol particulate matter sampled during the ACE-Asia campaign, J. Geophys. Res., 109, D19S10, doi:10.1029/2004JD004598, 2004b.

Simoneit, B. R. T., Medeiros, P. M., and Didyk, B. M.: Combustion products of plastics as indicators for refuse burning in the atmosphere, Environ. Sci. Technol., 39(18), 6961-6970, 2005.

Simoneit, B. R. T., Schauer, J. J., Nolte, C. G., Oros, D. R., Elias, V. O., Fraser, M. P., Rogge, W. F., and Cass, G. R.: Levoglucosan, a tracer for cellulose in biomass burning and atmospheric particles, Atmos. Environ., 33, 173-182, 1999.

Sinha, P., Hobbs, P. V., Yokelson, R. J., Blake, D. R., Gao, S., and Kirchstetter, T. W.: Emissions from miombo woodland and dambo grassland savanna fires, J. Geophys. Res., 109, D11305, doi:10.1029/2004JD004521, 2004. 
Smith, K. R., Mehta, S., and Maeusezahl-Feuz, M.: Indoor smoke from household solid fuels, in: Comparative Quantification of Health Risks: Global and Regional Burden of Disease due to Selected Major Risk Factors, edited by: Ezzati, M., Rodgers, A. D., Lopez, A. D., and Murray, C. J. L., World Health Organization, Geneva, 2, 1435-1493, 2004.

Streets, D. G., Bond, T. C., Carmichael, G. R., et al.: An inventory of gaseous and primary aerosol emissions in Asia in the year 2000, J. Geophys. Res., 108(D21), 8809, doi:10.1029/2002JD003093, 2003.

Streets, D. G., Zhang, Q., Wang, L., He, K., Hao, J., Wu, Y., Tang, Y., and Carmichael, G. R.: Revisiting China's CO emissions after the Transport and Chemical Evolution over the Pacific (TRACE-P) mission: Synthesis of inventories, atmospheric modeling, and observations, J. Geophys. Res., 111, D14306, doi:10.1029/2006JD007118, 2006.

Susott, R. A., Olbu, G. J., Baker, S. P., Ward, D. E., Kauffmann, J. B., and Shea, R. W.: Carbon, hydrogen, nitrogen, and thermogravimetric analysis of tropical ecosystem biomass, in: Biomass burning and global change - Remote sensing, modeling and inventory development, and biomass burning in Africa, edited by: Levine, J. S., MIT Press, Cambridge, 1, 249-259, 1996.

Tabazadeh, A. and Turco, R. P.: Stratospheric chlorine injection by volcanic eruptions: $\mathrm{HCl}$ scavenging and implications for ozone, Science, Washington, DC, US, 260(5111), 1082-1086, 1993.

TriData Corp.: Landfill fires: Their magnitude, characteristics and mitigation, Federal Emergency Management Agency, US Fire Administration, National Fire Data Center, Arlington, VA, 2002.

USEPA: Compilation of air pollutant emission factors Volume I: Stationary point and area sources, AP-42, Office of Air Quality Planning and Standards, Office of Air and Radiation, Research Triangle Park, NC, 26 pp., 1995.

USEPA: An inventory of sources and environmental releases of dioxin-like compounds in the United States for the years 1987, 1995, and 2000, EPA/600/P-03/002F, National Center for Environmental Assessment, Office of Research and Development, Washington, DC, 677 pp., 2006.

USEPA: Inventory of US Greenhouse Gas Emissions and Sinks: 1990-2005, EPA 430-R-07-002, Office of Atmospheric Programs, Washington DC, 2007.

Ward, D. E. and Radke, L. F.: Emissions measurements from vegetation fires: A comparative evaluation of methods and results, in: Fire in the Environment: The Ecological, Atmospheric, and Climatic Importance of Vegetation Fires, edited by: Crutzen, P. J. and Goldammer, J. G., John Wiley, New York, 53-76, 1993.

Yevich, R. and Logan, J. A.: An assessment of biofuel use and burning of agricultural waste in the developing world, Global Biogeochem. Cy., 17(4), 1095, doi:10.1029/2002GB001952, 2003.
Yokelson, R. J., Christian, T. J., Bertschi, I. T., and Hao, W. M.: Evaluation of adsorption effects on measurements of ammonia, acetic acid, and methanol, J. Geophys. Res., 108(D20), 4649, doi:10.1029/2003JD003549, 2003.

Yokelson, R. J., Christian, T. J., Karl, T. G., and Guenther, A.: The tropical forest and fire emissions experiment: laboratory fire measurements and synthesis of campaign data, Atmos. Chem. Phys., 8, 3509-3527, 2008, http://www.atmos-chem-phys.net/8/3509/2008/.

Yokelson, R. J., Crounse, J. D., DeCarlo, P. F., Karl, T., Urbanski, S., Atlas, E., Campos, T., Shinozuka, Y., Kapustin, V., Clarke, A. D., Weinheimer, A., Knapp, D. J., Montzka, D. D., Holloway, J., Weibring, P., Flocke, F., Zheng, W., Toohey, D., Wennberg, P. O., Wiedinmyer, C., Mauldin, L., Fried, A., Richter, D., Walega, J., Jimenez, J. L., Adachi, K., Buseck, P. R., Hall, S. R., and Shetter, R.: Emissions from biomass burning in the Yucatan, Atmos. Chem. Phys., 9, 5785-5812, 2009, http://www.atmos-chem-phys.net/9/5785/2009/.

Yokelson, R. J., Goode, J. G., Ward, D. E., Susott, R. A., Babbitt, R. E., Wade, D. D., Bertschi, I., Griffith, D. W. T., and Hao, W. M.: Emissions of formaldehyde, acetic acid, methanol, and other trace gases from biomass fires in North Carolina measured by airborne Fourier transform infrared spectroscopy, J. Geophys. Res., 104(D23), 30109-30126, doi:10.1029/1999JD900817, 1999.

Yokelson, R. J., Urbanski, S. P., Atlas, E. L., Toohey, D. W., Alvarado, E. C., Crounse, J. D., Wennberg, P. O., Fisher, M. E., Wold, C. E., Campos, T. L., Adachi, K., Buseck, P. R., and Hao, W. M.: Emissions from forest fires near Mexico City, Atmos. Chem. Phys., 7, 5569-5584, 2007, http://www.atmos-chem-phys.net/7/5569/2007/.

Yokelson, R. J., Ward, D. E., Susott, R. A., Reardon, J., and Griffith, D. W. T.: Emissions from smoldering combustion of biomass measured by open-path Fourier transform infrared spectroscopy, J. Geophys. Res., 102(D15), 18865-18877, 1997.

Zhang, J., Smith, K. R., Ma, Y., Ye, S., Jiang, F., Qi, W., Liu, P., Khalil, M. A. K., Rasmussen, R. A., and Thorneloe, S. A.: Greenhouse gases and other airborne pollutants from household stoves in China: a database for emission factors, Atmos. Environ., 34, 4537-4549, 2000.

Zuk, M., Rojas, L., Blanco, S., Serrano, P., Cruz, J., Angeles, F., Tzintzun, G., Armendariz, C., Edwards, R. D., Johnson, M., RiojasRodriguez, H., and Masera, O.: The impact of improved woodburning stoves on fine particulate matter concentrations in rural Mexican homes, J. Expo. Sci. Env. Epid., 17, 224-232, 2007. 